University of Louisville

ThinkIR: The University of Louisville's Institutional Repository

Electronic Theses and Dissertations

1937

\title{
A study of mahogany.
}

Roy A. Lawrence

University of Louisville

Follow this and additional works at: https://ir.library.louisville.edu/etd

Part of the Botany Commons, Forest Sciences Commons, and the Horticulture Commons

\section{Recommended Citation}

Lawrence, Roy A., "A study of mahogany." (1937). Electronic Theses and Dissertations. Paper 1826.

https://doi.org/10.18297/etd/1826

This Master's Thesis is brought to you for free and open access by ThinkIR: The University of Louisville's Institutional Repository. It has been accepted for inclusion in Electronic Theses and Dissertations by an authorized administrator of ThinkIR: The University of Louisville's Institutional Repository. This title appears here courtesy of the author, who has retained all other copyrights. For more information, please contact thinkir@louisville.edu. 


\title{
UEIVERSITY OP LOUISVIHLB
}

\author{
A STUDY OF KAHOQATY
}

A D1saertation

submitted to the Faculty

of the Oraduate sohool of the Univeralty of Loulsvilie

In Partial pulfilinont of the

Requirements for the Degree

of Master of Solence

Departmont of Chemletry

By

Roy A. Lawronoe

Yoax

1857 
Roy A. Lawionoe

A stomy of uhogax

Direotor,

Approved By

Rouding Comittees

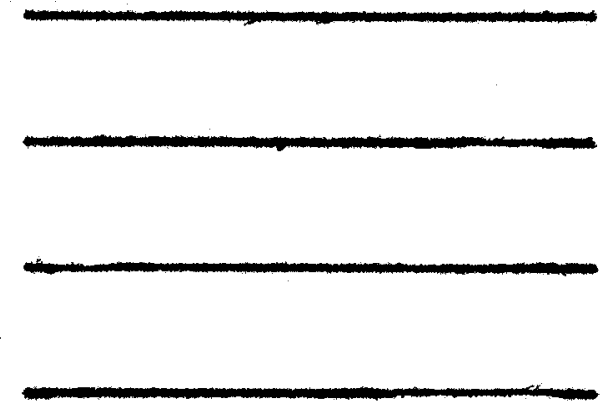

Dates Auguet 23, 2087 
Cotraness

Part $\mathbf{x}$

P480

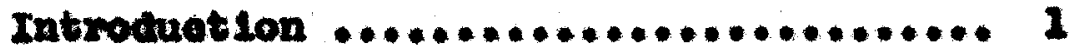

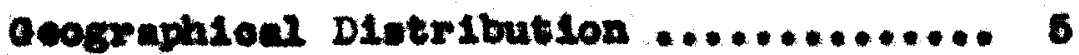

4. Hap I. Geograpinion Loottion of true Uhogenter t............ 7

B. Uop II. acograghion loontion

of Philipplae Vhogandes .......

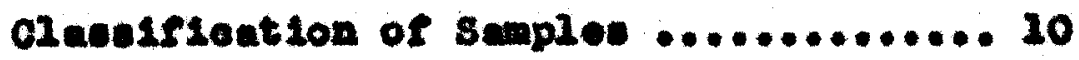

A. Proparation of semples ......... 11

B. Tabie I, clavelstation of

semplo

\section{Pat IS}

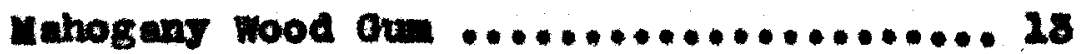

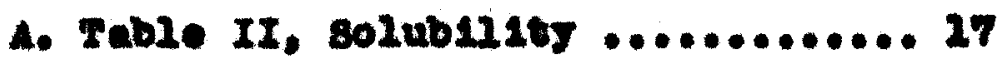

PAR IIT

Rrtraosion:

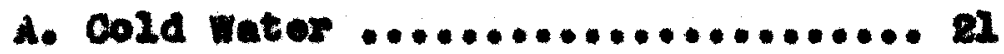

2. Table III, Doterminatione ... 86

B. Hot nater .................... 8

2. Table IV. Doteralnations .... 30

O. Ethor $\ldots \ldots \ldots \ldots \ldots \ldots \ldots \ldots \ldots \ldots \ldots \ldots \ldots \ldots \ldots \ldots, 38$

1. Tabie V, Doterminatione ..... 38 
CONHATS

coxinguad

Pege

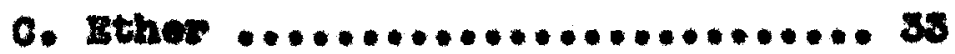

1. Tab2 Y. potominatons .... 38

d. Cold sodiun Byaroxlde ......... 38

1. Table VI, Doterintention ...40

D. Lot sodim Ejanoxid $\ldots \ldots \ldots \ldots \ldots \ldots 4$

1. Iabze VII. Doterulnatione ... 46

\section{PAR IV}

An contons

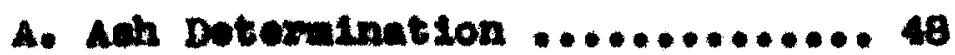

1. 2abIe VIII, Detominationt...80

\section{PARE}

Spoesede oratist

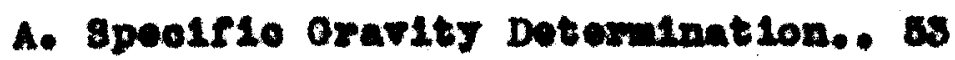

1. Table IX, Doterninatiose ... 85

\section{PART VI}

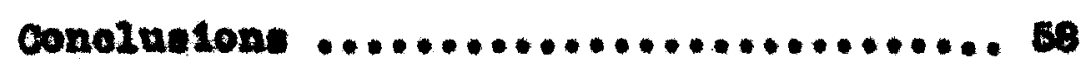

A. Pable $x$. gumary (Detominntions).60

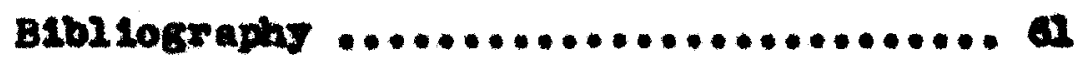


IWRODOCTIOH 
Introduction

To the average person, the ward, mahogeny, mont nothing wore than a wood from whloh furnlture is made. Verg fou people have over soen a ploce of this kind of wood in the green and unfinished state. We beve come to recognise thls kind or wood by the rathor dark brownish stain that 10 so obraotoristio of my ploces or rurntture conotruoted from nognny.

The origtn or the word, whogany, ceems to have been forgotten, but it is generally bollered by many to have had its origin in mative Afrion. It is probably the revied form of the native name for the tree. It la wid that the Afrioen native has the word, yahane, oning the largest tree or king or the toreet. It 1s very probable that this is the origin of the word, mogeny.

To the andyat, any kind of wood presents many everetes mahogany gives un a vat array of problems that are et111 to be explored and solred. So far. ohemloel rescarob has not ontered the vast flold that the atudy of hogany offars. Little la really known of the nature of the wood, 1ts compounde and thelr posalbillties. Nooorded ohomiatry showe that practionlly nothing bes beon accoupliohed as to a systembie investigation of the bard woods of troploal rogions. 
comerolally we find over fifty different kinde of wood bearing some form of the nam mahogany (6). According to botanieal informetion thle wood is not a plentiful as some mafacturere would have us think. It 1a ostimated that at least half of tho wood that is sold as hogany lo of nother specien, beering only the ollghtost rosoublence to mahogany. Botaniste bave clasalfied these woods Into ceveral olesces. The name of true mahogany bas been given to the mahogeny that it produoed in Fropleal Amorion, Ploride Keye, and the west Ind1es. The whogany that is grown in Afrion is rery eimlier in 1te properties to those of the true mahogany group. The ues of thls wood in the rurniture making Industry bad gained wde uase in Iurope ond Aporlca before the discovery of the simlinr wood along the west const region of Afriea. The differenose between the African speoles and those of rroploal Amerlos are secondery. These two groups are botanloally of the same gonus, however, they boar different solentiria names more beouse of the distriot geographion ranges of the two groupe. The whogant os as a olase are almost homogenoous a to atructure and texture (5). The offerences are attributed to growth oonditions, such as so11, ollmete, molsture and altitude. 
The color of the wood from difforent sourees varies frow a light brown to ack, radish brown. The apeofflo gravity of the different typee of mbogany range from .40 to .00.

In the Ph1lippine Is lands, we rind eoveral speoles of trees that beer a marked resemblenoe to the true maboganies. Thie wood has been imported and oold ae mahogany for many yeara. It is diffloult in somo Instanoes to distinguioh those woods arter finioh has been appllod. To the yood tooknologiat there are weny ways to dietinguiah tho so-0elled philippine moganles and the true mahoganles. An examination of the bark, lear, frutt and seed of those two olaseses revenl distinet differences (1). For Instance, the loaf of the PhIlipplne varioty is alople in etruoture; 1ts appouranoe resembles largo ole lear. Tho lear of the Iroploal American epeclos is compound in atruoture, reserbilng the lear of the ash troe. The soed of the true mogany tree is plattoned with the wing at one ond, wh110 the seod of the Bast Indian variety 1o rounded Ith several terminal winge forwing a oluster owerhat like the seed of our maple tree. Fer of the flowers of the trees of gropton amertee survive, wh1lo wost of those of the PhIlippine seoles develop Into single seeds. 
Pletures of berk of these varietses of trose show olouris diatinot difforenoes. The bark of the rroplend Amerian troe is more comse and grained than that of the Eact Indian opeoses. an outatanding chareoteriotic of these woods is the presmes or totel abeenos of dark, gliatening doposits of gumy abotanoes. In the pores or celle of the true anhogany apeoles and of the arrlean Mahogany, thore 10 preaent a not10oable quant1ty of th1s aubstanoo, wile in the Pullippine woode there is a total I ack of this aterial. Thle fonture 10 uwed by wod technologiete in verifying ompl os of mehogany (6). Another determining faotor is the color. Philippine varietie ranging rrom arown to tan wile the color of the trae varletile rangee from a brow to - dark roddish brown (6).

In vion of the faot that wo 11tt1. 1s known of the chenteal properties of these roode, it $10 \mathrm{mg}$ objective In this study rirot, to conduat an investigation of the

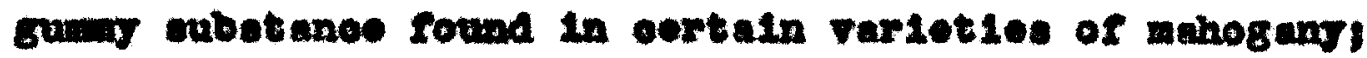
secondis, to invertigate the physedol properties as deternined through various extraotione of Arrioen makogany, Tropteal Anorion wahogeny, and tho somocl2ed Ph121ppino mahoganies, thiraly, to dotermine the opoosrio gravit1es of the above montioned woods and rinally to cotormine the an oontent of the severel apeoles. 
aeographical Distribution

Map I show the reglono miah produes the variotios of achogeny know as true maboragr (20). Afrioan mahogeny (Kaya ivorensid) is grown on the Irory coant. the cold Coevt, and Higeria, woot Afrion, Troploal amorican mahogeng (8wletenla morophyla) is produced In various ections of textes, cuben and plorialan whogence (Bwlotenle mahogend) are grown in the Morlde xoye and in the weot Indies. Honduras mehogany (8wieteala macrocarpa) is produood in rathor large quantitios in Brition honduras. Sorse varieties of this wood axe nov belng taken from parte of Bran11 and poru. The above moteload whogentes have aquilred many trade namos! som of the wore oommon are: Mexioan, Cuben, Itcaraguen, Tabasoo, San Jago, Clapata, Papema, Spanieh amerloan and oolombian. The trade neme uoually beara some portion of the neat of the town, port, or region fron wish 16 1. Aorived (5). The boat grade of this wood cones from slow growing trese on high, ary ground. It is rolativels hard, as oompared with the sort, eponsy mahogeng obtalned from the rapld-growing trees in the wolst 0012 of the Lowlands and coastel roglons.

The mehogany thet 1s produced elong the west coant of Arriea is of falr quality. The wood from this reglon poseesees nelther extremes of eolor nor donalty. These 
trees grow to en unumal a1se, fiving boerde of exposelve wath and length. Beomuse of this extrees widh, the 108" are out into vencors and are uned extensively in the rurniture 10dustry. The hardost of the nehogenies are produced in Forida, the donetey of this wood being we high as .00 , wile other epecies are as $10 \mathrm{w}$ es 40. True annual growth rlage are found only in the rood that 10 grow farther worth then Britich Hondurae. Thowe ringe of the couthern epeales are uneven, due to the fact that growh in sowe form contimues through out the rear. The wood that 1s produoed north of Britich Bondurat conmonly wow in tranoverse seotsonm diatinot annual erowth ringe (8). 
MAP I

GEOGRAPHICAL LOCATION OF AFRICAN

MAHOGANY AND THE SO-CALLED TRUE MAHOGANIES (10)

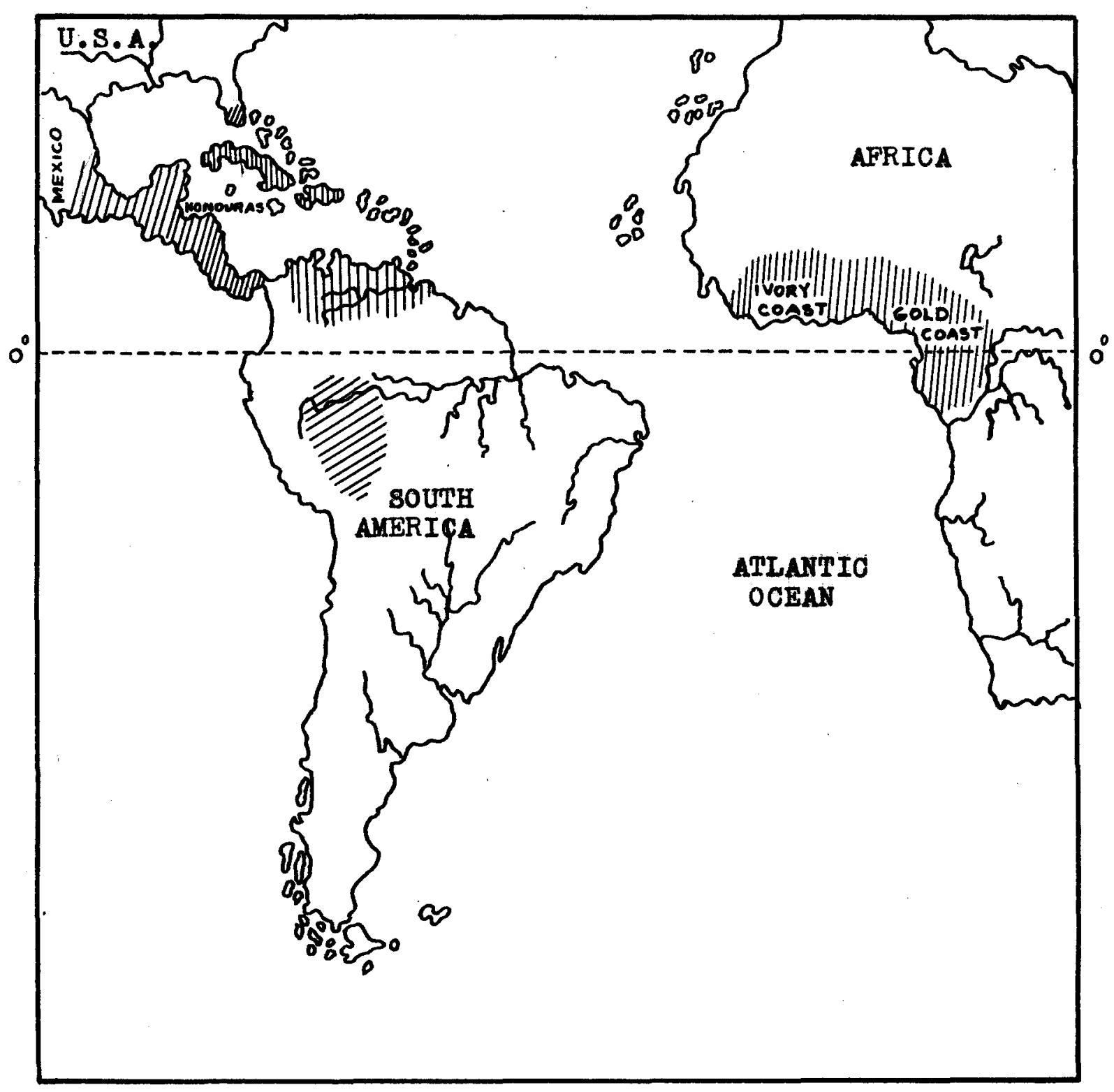


MAP II

GEOGRAPHICAI LOCATION OF

PHILIPPINE MAHOGANIES (10)

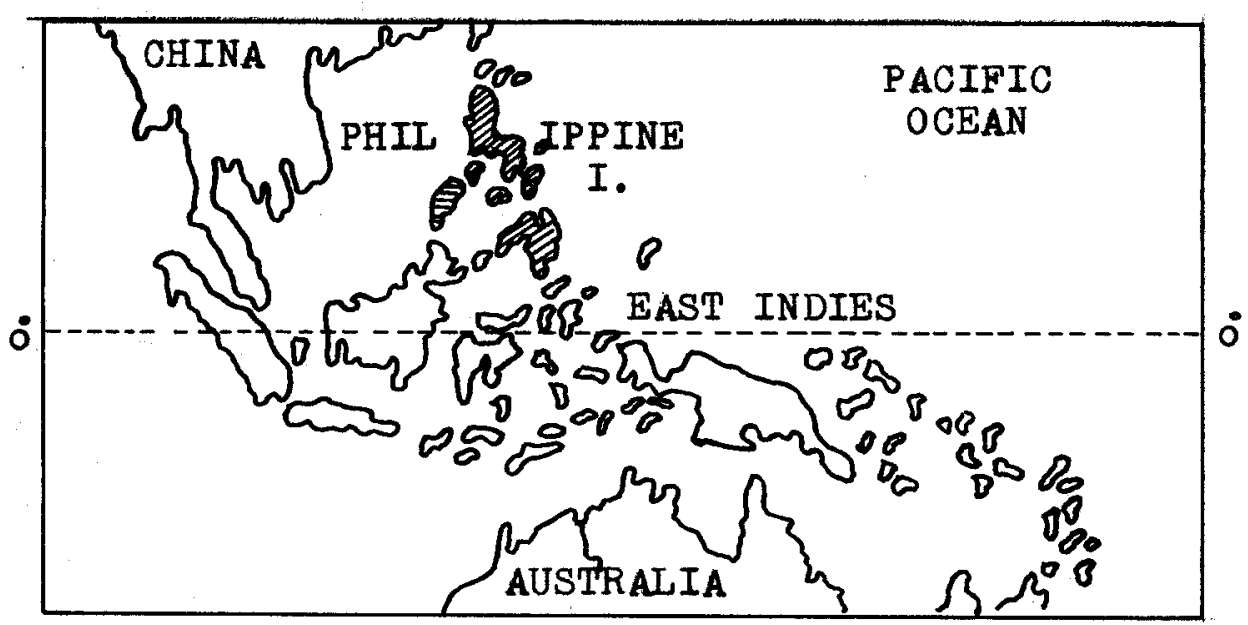

From the Philippine Islands come several speciec of wood that aro known as the so-olled PhIllppine mahoganles. Tangulle and Red Lavan constitute the bulk of the Phillppine yhogany sont to the United stites and are generally used as abstitute for true mahogany in the furniture manufaoturing industries. White Laun, Almon and Bagtioien are lso Inoluded In the shipments of wood from the Philipplnes. Botanioally, there 1a marked diatinetion botween Phllippino mahoganles and true mahoganios frow Africa and Troplcal Amorica. However, it sometimes is quite a problem to distingulah between the woods after several coets of finlsh have been applied. 
The Ph1l1pplne mahoganies as a olas are nolther a hard nor as heary as the true mahoganies. The pores are very distinot on suoothly cut surfaces, and hare fairly uniform grain chameteristios. It seasone very we11, and does not warp nor split eas11y. Almon is probably the sortest of the PhIlipplne ahoganiea. It vamies from 11ght brown to tan in color, and is light with course grain characteristics. of this class of woods, Tangulle is the best. It 1a somewhat harder, heavier, atronger and finer in texture than either the Iauane or Bagtiolan. 
D1sousetion of samples

The samples uecd in this study were obtalnod from companies Importing these speoles. Samples of cereral gum pookets were obte Ined frow the Mongel Company of Loulevilie. Samples of Afrioun mohogny, Maxican mahogeny, Britioh Honduras mogegeny, Cuban mogeng and ploridien mbogeny wore cocured from the same oompany. Tho Inaular tumber compeny of Phlindelph1a, exportere of PhIllpplne mahogany, and the pore Lumber company of st. Louls furntahed samples of the following Ph111ppine mahoganies, White Lamn, Red Luan, Tangulio and Bagtiolen.

Woh of the above mentioned samples were forwarded to the Un1ted states Forest Produote Laboratory for verifloation. Fublece of wood proved to be en authentio sample (20). The anmples wore obtalned from kIIn arled boerde that bad been out for at least two jears. The samples obtained from the Mengel company were probably ten yeare old. Mo Information oould bo obteined, as to the ise of the tree nor the locetion of the plece from which the eamples were out. All aamples were cut from the heart wood.

The gum pocket asmples wore from African mahogany wood, Moxican mbogany, and ploridian mogany, Samples of the gum were obtelned from the siftinge of the other wontioned sanples of wood. 
Proparation of samples

Ea oh pleoe of wood wes converted into tine cawduat by uoling very fino tooth aar. The sav and table was carorully oleanod bofore cab outting. Thle sawdust was offted through a fifty mosh sleves the partieles faling to pase this wob wore rejooted. The sawdust anoples were pleced in alr-tight oonteinors. The gume of the severni pookte were removed and aleo plaoed in olosed containors.

In the extraction experimente, the orginal samples were conducted through a erlee of extractions. In cach case, threo aruples were used and caloulatione woro given for the mean as well as the three rune. The percontages given wore in terwe of the welght of the sawplos for the partiouler extreotion.

All doterminetions in this study wore baeed on oren-dry $\left(100^{\circ} \mathrm{C.}\right)$ samplos. It weo determined thet anples required from four to $1 x$ houre arying in order to reaoh a constant wight. 
TAES I

OLAB IFICATIOX of sAupLes

\begin{tabular}{|c|c|c|c|}
\hline common lina & $\begin{array}{l}\text { getentels } \\
\text { nes }\end{array}$ & $\begin{array}{l}\text { Eutive } \\
\text { Eabitat }\end{array}$ & color \\
\hline $\begin{array}{l}\text { Arplonn } \\
\text { mhogen }\end{array}$ & $\begin{array}{l}\text { Enga } \\
\text { irorenete (s) }\end{array}$ & $\begin{array}{l}\text { West oonet } \\
\text { or arten }\end{array}$ & $\begin{array}{l}\text { Redaloh } \\
\text { Dram } 6\end{array}$ \\
\hline $\ln$ & $\begin{array}{l}\text { seletonis } \\
\text { waropirina }\end{array}$ & $\operatorname{Lin} 100$ & $\begin{array}{l}\text { That } \\
\text { Redileh } \\
\text { Brena }\end{array}$ \\
\hline $\begin{array}{l}\text { Ouben } \\
\text { thogany }\end{array}$ & $\begin{array}{l}\text { siletonit } \\
\text { mognt }\end{array}$ & West Indies & $\begin{array}{l}\text { Dawk } \\
\text { Reddish } \\
\text { Breme }\end{array}$ \\
\hline $\begin{array}{l}\text { Eondures } \\
\text { Whoteny }\end{array}$ & $\begin{array}{l}\text { entetonde } \\
\text { moroonxpm }\end{array}$ & $\begin{array}{l}\text { Worth Britioh } \\
\text { Iondures }\end{array}$ & $\begin{array}{l}\text { Rewaleh } \\
\text { Romn }\end{array}$ \\
\hline $\begin{array}{l}\text { gomialen } \\
\text { mogeny }\end{array}$ & $\begin{array}{l}\text { srietenia } \\
\text { mpognt }\end{array}$ & plorida Leye & $\begin{array}{l}\text { Razk } \\
\text { Redileh } \\
\text { Beom }\end{array}$ \\
\hline $\begin{array}{l}\text { Buctiolan or } \\
\text { Philippino } \\
\text { inoging }\end{array}$ & $\begin{array}{l}\text { Parashorea } \\
\text { inanonen }\end{array}$ & $\begin{array}{l}\text { Ph111pplno } \\
\text { Ielande }\end{array}$ & $\begin{array}{l}\text { Light } \\
\text { Brown }\end{array}$ \\
\hline $\begin{array}{l}\text { mite Inum } \\
\text { or Phi21pplne } \\
\text { mogn }\end{array}$ & $\begin{array}{l}\text { Pentuene } \\
\text { Contorten }\end{array}$ & $\begin{array}{l}\text { Pn121ppino } \\
\text { Inlnnde }\end{array}$ & $\begin{array}{l}\text { tedst } \\
\text { Bxom }\end{array}$ \\
\hline 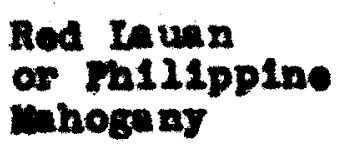 & $\begin{array}{l}\text { Bhorea } \\
\text { nofroen is }\end{array}$ & $\begin{array}{l}\text { Ph121ppino } \\
\text { InLnde }\end{array}$ & $\begin{array}{l}\text { Reddieh } \\
\text { Broma }\end{array}$ \\
\hline $\begin{array}{l}12 p \\
\text { sim }\end{array}$ & shoren & $\begin{array}{l}\text { Pa111pptae } \\
\text { Inlande }\end{array}$ & $\begin{array}{l}\text { Leht } \\
\text { Bromn }\end{array}$ \\
\hline
\end{tabular}




\section{PARR II}

\section{YAHOOAX WOOD OV}


mograny wood our

An examination of the 11terature revele thet no eyotematic attempt bas been wade to oxamine the gums of varloue trees. The gum subetanos found in the co11. of the true maghany opecles presente an interesting problow. Ite presence is used as a determining factor in distingulahing true mabogny wood from that of other epeciee. Acoording to derinition, (25) wood gun 1s tranezucont, worphous subatance, most of the gums belng elightly soluble in weter and praetionily all possessing the property of arelling whon allowed to romin in water for a length of time. mhogeny good gum it a tranuluosnt, amorphous eubetanee having the property of beooming elightly coft in water, but uniske wost gum it doos not well when slloned to sokk.

The wood gume are generally coneldered to be decompostion producte of cellulose (15), reauling from the aotion of come hydrolyt10 formont, woundly atimulated by cose unfarorable condition of growth, some injury, or some morbld condition. In mahogeny trees, the formation of this substance is doubtlese due to changes of degradation in the cell wall. The substance is found with in tho cell 1 toelf and in epaces rormed by the breaking down of numerou oelle 
called gun pookete of gue atreake. In African whogany and in the somealled true mhoganles, thle product can be seen quite ons11y with the ald of a 10w power hand lans. In spruce and other coniforous troos, It is found in distinat roooptades, known as rea In-pasasges.

Acoording to schorger, (13) rood gum oowes under the clase of compounds known as the hemleolluloses. He defines a bouloediulose a polysecohnride, soluble In dilute alkall and convertible into simple sugare by heating w1th dilute aolds. Uahogeny wood fum can bardif be clessed as a true hemloellulose as it cannot be dissolved in dilute almil, not osn It be conperted Into alaple angare through tho aotion of dilute aclds and hoat.

The rirat stop in ov Investigation of this gum wae to exporiment with 1 ta solub121ty. Table I 11luatratea the various solvents ued in an attempt to diseolve the subetanee. The samples used were taken from gum pookets and from samples of Afrioan and Troploal Amorioen mahoganles that continined an unueus a sount of the materlal. Varlous phyalcal means of soparating the materlal from the sawdust ware tried, but no eatiefactory wethod was found that would bring about a complote eoparation. It was found that some of the gum could be remored by ahming the 
sawdust with othor, and then quiokly pouring off the ethor. This procese would leave amil amount of the ubatanoe in the bottom or the container. In many cases the gumm substance was allowed to digest in a portion of the solvent for several daye. but in some cosen, whore this was Impraction 1, a tost plate mothod wes used. A teet plute or watoh glase was used, a portion of the material wes obtalned with the ald of a hand len: and allowed to remin $2 \mathrm{n}$ contaot with the solvent for about an bour. Ang reaction was carefully watohed through the hand Iens.

Tho eubetanee proved to be insoluble in all tho organio co2ronte uaed. No mothod other than mydrolye 2. could be round to reave the material from the rood. This was done by the constant bolilng with flve percent sodiu brdroxide over a perlod of fourteen houre, humerous extraetion were carried out with houriy examinatione of the sewdust to deterwine the length of time neceseary for its complete extraction. The filtrates from these extreotlone falled to give proolpltate upon neutralisation with aolde. The Plitre to obtained is the extraction of samdust with oold sodiun hydroxlde verg ously gave a proolpltate upon the addition of an eold. I might add thet the extration with bolling adium hydroxide were conduoted on sapples that had been previously 
extrated with the oold reagent, and which otild whow the presenes of the gum.

After falling to obtain a proolpitate with the we of an acid, other mothode were tried and it was found that an equal voluae of 96 percent $100 \mathrm{hol}$ gave - rlocoulent preolpitate or dark reddion brown color. In several houre this meterlal bed eottled to the bottow of the container. It was focovered on a filter and arled. This was found to be very coluble In water end oould be precipltated crom ite water solution by the addition of en equal volume of - Loohol or acetone. Varlous methods of separating the mixture into pure compound wore ontirely unsucoeseful. No mothod could be devised to wepa re it through orystalization. Practional precipltation, cooling or houting.

This material proved to be insoluble in the organlo colvente; however, thero wa a alight sortenlng In Gasoline, Bensene and Kerosene. 
TABIE II

SOLUBILTY OF YAHOOAKY OU:

\begin{tabular}{|c|c|c|c|}
\hline solvent $(\theta)$ & $\begin{array}{l}\text { Timo } \\
\text { in } \\
\text { Boure }\end{array}$ & cond $1+10 \mathrm{~ns}$ & solub121ty \\
\hline wator & 148 & $\begin{array}{l}\text { Prequent } \\
\text { ahaking }\end{array}$ & $\begin{array}{l}\text { - light } \\
\text { coftening }\end{array}$ \\
\hline wator & 84 & rofluxed & $\begin{array}{l}\text { - light } \\
\text { sortening }\end{array}$ \\
\hline Aloohol & 248 & $\begin{array}{l}\text { frequent } \\
\text { enaking }\end{array}$ & ineoluble \\
\hline Aleobol & 14 & ror zuxed & Intoluble \\
\hline Bthor & 148 & $\begin{array}{l}\text { Erequent } \\
\text { abuiting }\end{array}$ & Insoluble \\
\hline Ether & 84 & sorluxed & Ineoluble \\
\hline Bensene & 148 & $\begin{array}{l}\text { Eroquent } \\
\text { makine }\end{array}$ & $\begin{array}{l}\text { I1ght } \\
\text { eortentag }\end{array}$ \\
\hline Oacoline & 248 & $\begin{array}{l}\text { Eroquent } \\
\text { abaking }\end{array}$ & $\begin{array}{l}\text { el1ght } \\
\text { eortening }\end{array}$ \\
\hline rorosene & 148 & $\begin{array}{l}\text { erequent } \\
\text { obuking }\end{array}$ & $\begin{array}{l}\text { elight } \\
\text { eoftening }\end{array}$ \\
\hline Acetone & 248 & $\begin{array}{l}\text { frequent } \\
\text { obaling }\end{array}$ & $\begin{array}{l}\text { - l1ght } \\
\text { cortening }\end{array}$ \\
\hline $\begin{array}{l}\text { Inoquer } \\
\text { Thinner }\end{array}$ & 148 & $\begin{array}{l}\text { eroquent } \\
\text { shaking }\end{array}$ & Insoluble \\
\hline $\begin{array}{l}\text { Sodius } \\
\text { Fydrox } 1 d e-5 s\end{array}$ & 148 & $\begin{array}{l}\text { frequent } \\
\text { obaking }\end{array}$ & $\begin{array}{l}\text { elight } \\
\text { oortening }\end{array}$ \\
\hline $\begin{array}{l}\text { sodiun } \\
\text { Apdroxide-s }\end{array}$ & 24 & rerluxed & bydrolysela \\
\hline Iurpent: & 148 & $\begin{array}{l}\text { Eroquent } \\
\text { ohaking }\end{array}$ & Insoluble \\
\hline
\end{tabular}


TABLB II

COMT IMUED

\begin{tabular}{|c|c|c|c|}
\hline Solvent & $\begin{array}{l}\text { rime } \\
\text { ln } \\
\text { gours }\end{array}$ & conditions & solub1lity \\
\hline $\begin{array}{l}\text { Wothyl } \\
\text { Alcohol }\end{array}$ & 148 & $\begin{array}{l}\text { Irequent } \\
\text { shaking }\end{array}$ & Ineoluble \\
\hline $\begin{array}{l}\text { Sodiun } \\
\text { Carbonate }\end{array}$ & 8 & bolling & $\begin{array}{l}\text { alight } \\
\text { oortening }\end{array}$ \\
\hline $\begin{array}{l}\text { Bormx } \\
\text { solution }\end{array}$ & 3 & bolling & Ineoluble \\
\hline Perborte (4) & $s$ & bolling & Incoluble \\
\hline $\begin{array}{l}\text { somisetser" } \\
\text { Reacent: }(7)\end{array}$ & 148 & $\begin{array}{l}\text { Srequent } \\
\text { onding }\end{array}$ & $\begin{array}{l}\text { - } 11 \mathrm{ght} \\
\text { eostaning }\end{array}$ \\
\hline $\begin{array}{l}\text { Carbon Tetre } \\
\text { Chlorlde }\end{array}$ & 1 & test piate & Insoluble \\
\hline $\begin{array}{l}\text { nitro } \\
\text { Bensone }\end{array}$ & 2 & $*$ & Insoluble \\
\hline $\begin{array}{l}\text { Aoot10 } \\
\text { Aold }\end{array}$ & 1 & - & Insoluble \\
\hline $\begin{array}{l}\text { Mitrio } \\
\text { Aold (a1lute) }\end{array}$ & 1 & $\bullet$ & Ineoluble \\
\hline $\begin{array}{l}\text { sulphurio } \\
\text { Aeld (dilute) }\end{array}$ & 2 & - & Ineoluble \\
\hline Toluone & 1 & 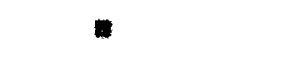 & Ins oluble \\
\hline $\begin{array}{l}\text { Tartario } \\
\text { iold }\end{array}$ & 2 & $n$ & Inooluble \\
\hline And Ithor & 1 & * & Ineoluble \\
\hline xiene & 1 & $\bullet$ & Insoluble \\
\hline
\end{tabular}


TABLE II

CONP INUED

Solvent

In

Oond1 t 1 ons

solub111ty

Houre

Bonza ldebroe

1

teet plate

Insoluble

Ioo $\operatorname{Amp} 1$

1

*

Insoluble

Aootate

Acetophenone

1

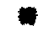

Insoluble

Buty 1

2

$-$

1neoluble

Aloobol

Buty 2

Bromide

1

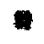

Insoluble

cyolo-

1

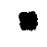

Insoluble

hoxane

carbon

Dieulfide

2

Aootio

Anhydride

1

a

Ineoluble

Form Id obyde

1

1

1neoluble

Ethy lene

Bromide

1

i.

Insolublo

Land

2

1

Ineoluble

A cotrate

Hydroohlor10

1

a

Ineolublo

Acia Cone.

soap 
PABLE IT

CONP IXUED

Solvent

$$
21 \text { ine }
$$

cond 1 tione

solubl11ty

Eoure

01aolaz

nootio nold

$\theta$

Srequant

obukins

Purene 2

$\mathbf{1}$

teat plate

Lnooluble

Eopta ld abyde

1

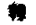

Incoluble

zino Chloride

$\boldsymbol{I}$

bo121ng

1nooluble

solution (16)

Aoety 1

Chloride

1

Alochol and

Water vixture

24

requent

erwing

Ina $024 \mathrm{~b} 20$

Pote es 1 un

Eydrox $1 d$ e $10 \%$

84

Frequent shakins

insolubie

Amon Iun Fyeroxide

24

Sroquent abuking

Ineoluble

rrequent

11ght chnking eortening 


\section{PART III}

\section{EXTRACX LOHS}




\section{cold Weter Extractione}

In these extmotione no ttempt wa mas to Idantify the extraneous components of the wood, however, wention 111 be made of the possibilities In each case. The term extranoous componente has been used by Hawley and 1se (B) to designate number of subutances that are preaent in certain woode whioh are often crouped together under the generel heading of axtruetives. These abstanees are found in the woody tiseue. but are not considarad In integral part of the oell wall. They oan waully be axtracted with variou solvents.

thny of these extraneous componenta heve a decided comerolal value. In most cheos 11 ttie io realiy known as to their true orgin and the function In the plant. some of these subetances have been investigated onlefly for medicinal purposes. The sluoos 1des offer a elese of compounds that can be extracted wth weter or leohol (8). Among the Q lucoelden that have galnod prominence is Aroutin, - powerful aluretio, extreted from the berm tree. salioin, found in the bark of the 1210 and Popler trees, is used in nedieine as antipyretio. Phioridsin, found in the bark of eruit trees, is aned as an antiporiod10. 
Contferin, the glueoulde of the fir tree, Is of 1mportanoe as the atarting point for the oynthesis or vanizin $(8)$.

In some investigationa, It was found that oortain troes poseess netural dyesturfs that oun be extracted with water, aloohol or ether (8). some of these ayestuffe are at112 of comerclul value, however, the progress of the synthetio dye induetiy has ereatly lossoned the demand for them. The poselbilities of the mahogany troe, as to 1 te mediolnal and comerclal value, are yet to be investigated by ohemian 1 researah. At present, it is bolng used only in the manufature of rurnd ture.

\section{Experimented}

Table III glves the resulte obtained from the cold water extraction of the camples proviously alaseiried. The results are based on the oven-dry $\left(205^{\circ} \mathrm{C}.\right)$ semple. The procedure used in these extractions is as followe; The saples were placed in the oven and aried for $1 x$ houre at 1050. Three samples of each of the nine woode were carafuliy welghed and placod in rinske. They were ellowed to digent in $200 \%$. c. of cold water for a period of 1xty a $2 x$ hours. 
The P12tering prooess wes acoospliahed with a Buobner funne1. The ir aried out the eanduet so that It could be removed Ithout an epprealable lose of materin 16. The uamploe wore tranoferred to an eraporating alsh and allowed to dry in the oven for a alx hour period at $105^{\circ}-120^{\circ} \mathrm{C}$. It was then pleoed in a desiccator unt11 cool, after whioh it was trancferred to welghing bottle and weighed. This had to bo acoomplished quiokly, as it wa found that the dried meterial took on noleture repldiy. The aumples were then placed in fluclas in readineas for the next axtra otion.

The table aleo glves the colore of the flltrates In ea ob extraction. An axamination of the table reveals thet tho eomeniled true boganien yield a nigher peroent of water ooluble ubatance than those of the gast Ind1es. Aleo, it sooms, that tho amount of water coluble wateriale is in oome way related to the specifle grivity of the mood, (see rable ax) the heavier tho wood the graster the amount of water eluble materialo. The table show thet the anmples of Plorialen wahogny are entirely out of IIne ith the enloulatione for the otber woode ued in the experimentio 
Floridian mogany is the heavieat of all the woode in th1s olese, however, the writer fully reallses that one troe does not give true plature or the species. It was found in some instences that trees of the same opecies growing within a relutive short distance from each other gave quite different results in thoir ana $1 y \cdot 18(8)$.

A. previously stated no serious attempt wa made to deternine the subatances extracted, however, in eab case the filtre to was orated to dryness in order to deterwine the nature or the extractod materiale. The residue from the cold water extraotion was chooolate oolored subatance. No cryotals were formed during the evaporation nor could any be formed through oooling, heating, to.

The resulte given in these doterminatione are Indicetive of what one might expect to rind in a thorough guntitetive analysis using amples from many troes of the apeoles. 


\section{TABLE III}

RESULTS OP COLD WATRH EXTAACTIOHB

samplea oron-dy $\left(106^{\circ} \mathrm{C}.\right)$

\begin{tabular}{|c|c|c|c|c|c|}
\hline speoles & $\begin{array}{l}\text { Wolght } \\
\text { of } \\
\text { saxplos }\end{array}$ & $\begin{array}{l}\text { rimo } \\
\text { In } \\
\text { Houre }\end{array}$ & $\begin{array}{l}\text { cond1- } \\
\text { t1ona }\end{array}$ & $\begin{array}{l}\text { color } \\
\text { of } \\
\text { piltrate }\end{array}$ & $\begin{array}{l}\text { Poroent } \\
\text { Extreot- } \\
\text { d }\end{array}$ \\
\hline $\begin{array}{c}\text { African } \\
\text { mogany } \\
\text { II }\end{array}$ & 4.0008 & 66 & $\begin{array}{l}\text { Irequent } \\
\text { shaking }\end{array}$ & $0 . x \cdot r \cdot 2(11)$ & 3.68 \\
\hline $\begin{array}{c}\text { Aerioan } \\
\text { wahogams } \\
\text { pe }\end{array}$ & $4.000 \mathrm{~g}$ & $\bullet$ & $*$ & - & 3.56 \\
\hline $\begin{array}{c}\text { Afrioan } \\
\text { wahogany } \\
\# 5\end{array}$ & 4.0008 & - & - & n & 3.88 \\
\hline $\operatorname{man}$ & 4.0008 & * & $\bullet$ & 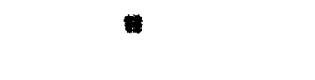 & 3.68 \\
\hline $\begin{array}{c}\text { moxioan } \\
\text { mogeny } \\
y 1\end{array}$ & $4.000_{8}$ & 66 & $\begin{array}{l}\text { frequent } \\
\text { sbuking }\end{array}$ & $0 . Y$. & 3.65 \\
\hline $\begin{array}{l}\text { Mexioan } \\
\text { Wahogany } \\
\text { f }^{2}\end{array}$ & $\$ .0008$ & $*$ & $n$ & - & 3.30 \\
\hline $\begin{array}{c}\text { Moxionn } \\
\text { mahogeny } \\
\text { so }\end{array}$ & $4.000 \mathrm{~g}$ & - & " & * & 3.80 \\
\hline man & $4.000 \mathrm{~g}$ & 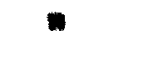 & 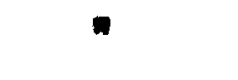 & " & 3.58 \\
\hline $\begin{array}{l}\text { Cuban } \\
\text { whogeng } \\
\text { 年 }\end{array}$ & $4.000 \mathrm{~B}$ & 66 & $\begin{array}{l}\text { frequent } \\
\text { shaklng }\end{array}$ & Y.0. & 6.30 \\
\hline $\begin{array}{l}\text { Cuban } \\
\text { Wahogany } \\
\text { to }\end{array}$ & 4.0008 & $*$ & " & $n$ & 5.76 \\
\hline $\begin{array}{c}\text { Cuban } \\
\text { wabogany } \\
\qquad 5\end{array}$ & $4.000 \mathrm{~g}$ & $\bullet$ & * & $*$ & 5.71 \\
\hline $\mathbf{E A}$ & $4.000 \mathrm{~g}$ & 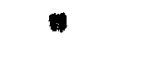 & 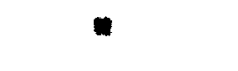 & 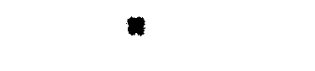 & 5.62 \\
\hline
\end{tabular}


TABLE III

CONT IMUED

\begin{tabular}{|c|c|c|c|c|c|}
\hline speoles & $\begin{array}{l}\text { wolght } \\
\text { of } \\
\text { samples }\end{array}$ & $\begin{array}{l}\operatorname{xim} \\
\text { In } \\
\text { Iloure }\end{array}$ & $\begin{array}{l}\text { Conal- } \\
\text { tlone }\end{array}$ & $\begin{array}{l}\text { color } \\
\text { of } \\
\text { plitrate }\end{array}$ & $\begin{array}{l}\text { Percent } \\
\text { Retraot- } \\
\text { od }\end{array}$ \\
\hline $\begin{array}{c}\text { Rond uras } \\
\text { hogany } \\
\text { II }\end{array}$ & 4.0008 & 68 & $\begin{array}{l}\text { frequent } \\
\text { shoking }\end{array}$ & $0 . x$ & 2.87 \\
\hline $\begin{array}{c}\text { Bondures } \\
\text { Mahogaro } \\
\text { na }\end{array}$ & $4.000 \mathrm{~g}$ & n & - & 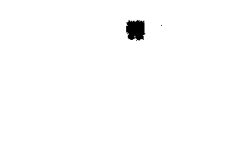 & 1.88 \\
\hline $\begin{array}{l}\text { Honduras } \\
\text { mahogany } \\
\text { \#s }\end{array}$ & $4.000_{\mathrm{B}}$ & 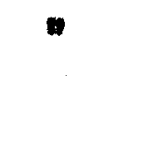 & $\bullet$ & 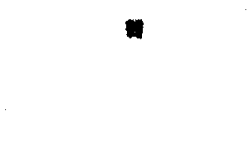 & 2.37 \\
\hline $\max$ & $\$ .0008$ & " & 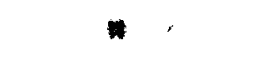 & $n$ & 1.88 \\
\hline $\begin{array}{c}\text { Loridian } \\
\text { mogany } \\
\end{array}$ & 4.0008 & 66 & $\begin{array}{l}\text { erequent } \\
\text { obmings }\end{array}$ & Ү.0. & 15.38 \\
\hline $\begin{array}{c}\text { Lorid Lan } \\
\text { mogeny } \\
y\end{array}$ & $4.000 \mathrm{~g}$ & 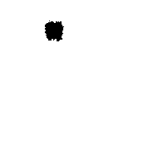 & $\bullet$ & $n$ & 14.08 \\
\hline $\begin{array}{l}\text { Moridian } \\
\text { mogny }\end{array}$ & $4.000 \mathrm{~g}$ & 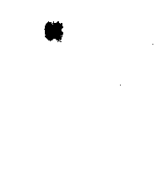 & $*$ & " & 15.08 \\
\hline meax & $\$ .000 \mathrm{~B}$ & $\bullet$ & - & 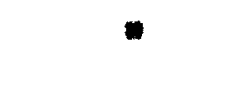 & 25.12 \\
\hline $\begin{array}{c}\operatorname{Beg} \operatorname{lan}_{42} \\
\tan \end{array}$ & $4.000 \mathrm{z}$ & 66 & $\begin{array}{l}\text { frequent } \\
\text { sbaking }\end{array}$ & $\begin{array}{l}\text { no } \\
\text { volor }\end{array}$ & 1.60 \\
\hline$\frac{8}{\operatorname{tos} \theta}$ & $4.000_{8}$ & " & $*$ & * & 1.77 \\
\hline $\begin{array}{c}\text { Buge } \\
+10 \ln ^{\circ}\end{array}$ & $4.000_{8}$ & $n$ & $"$ & " & 2,49 \\
\hline uBAI & $4.000 \mathrm{~g}$ & 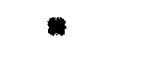 & 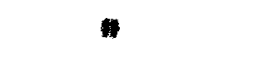 & 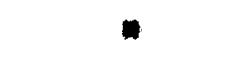 & \\
\hline
\end{tabular}


RADTE III

comr Inued

\begin{tabular}{|c|c|c|c|c|c|}
\hline Apaoles & $\begin{array}{c}\text { Welght } \\
\text { of } \\
\text { anmples }\end{array}$ & $\begin{array}{l}\text { Plwe } \\
\text { in } \\
\text { Houre }\end{array}$ & $\begin{array}{l}\text { comd1- } \\
\text { tions }\end{array}$ & $\begin{array}{l}\cos 2 x \\
o r \\
\text { plitinto }\end{array}$ & $\begin{array}{l}\text { Peroont } \\
\text { memot- } \\
\text { ad }\end{array}$ \\
\hline 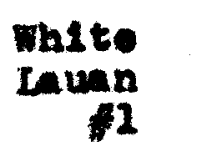 & $4.000 \mathrm{x}$ & 66 & $\begin{array}{l}\text { exoquent } \\
\text { makins }\end{array}$ & 1.0 .1 .9 & .71 \\
\hline $\begin{array}{r}\text { Hhes } \\
\text { Lann } \\
7 \%\end{array}$ & 4.0008 & " & - & - & 78 \\
\hline $\begin{array}{r}\text { Whet } \\
\text { Len } \\
\text { As }\end{array}$ & $4.000 \mathrm{~g}$ & 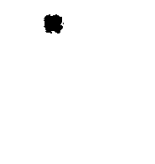 & - & $*$ & 96 \\
\hline MEA & $4.000 \mathrm{~g}$ & - & . & 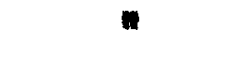 & .71 \\
\hline $\operatorname{Rod}_{n 1}$ & $4.000 \mathrm{~g}$ & 66 & $\begin{array}{l}\text { requent } \\
\text { malins }\end{array}$ & $\mathbf{I . 0}$ & .80 \\
\hline$\underset{R=}{\text { Red }}$ & 4.0008 & $\bullet$ & $"$ & $\bullet$ & .77 \\
\hline $\begin{array}{l}\text { Rea } \\
\text { Inm }\end{array}$ & $4.000 \mathrm{~s}$ & - & - & $=$ & .70 \\
\hline MEA & 4.0008 & $*$ & $\bullet$ & - & .76 \\
\hline $\begin{array}{c}\operatorname{mang-} \\
\mathrm{a} 1 \mathrm{H}^{-}\end{array}$ & $4.000 \mathrm{~g}$ & 66 & $\begin{array}{l}\text { erequent } \\
\text { ehring }\end{array}$ & 0.7 .1 .9 & 2.02 \\
\hline 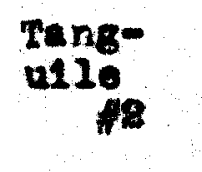 & $4.000 \mathrm{~g}$ & ต & 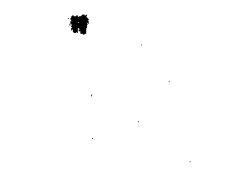 & - & .09 \\
\hline $\begin{array}{l}\operatorname{man} \\
\mathrm{n} 1\end{array}$ & $4.000 \mathrm{~g}$ & a & 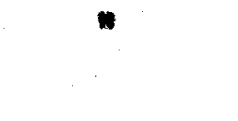 & " & .0 \\
\hline$m$ & $4.000 \mathrm{~g}$ & 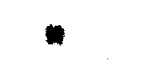 & 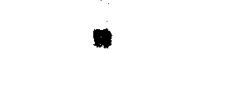 & 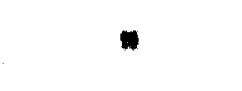 & 10 \\
\hline
\end{tabular}


Hot water Butraot Lons.

The tamnine hoid an importent place ewong the extrancous component of wod that oan be extracted with hot water (8). Within reoent joare the tannin content of a mober of trese hae been inveutigated; howerer, the 21terature does not revel any resenseber on the tannin content of the nahogeny trevs. The tannins are rexy widely dietributed, oocuring in many alfrerent woode, but comparatively for of them have boen inveatigated. Iltele is realiy known of theis true chemioel conatitution. The prinolpal uees of the tennin compounds are found in the leather and the ayeing incuatry.

Bxportmente2

The acuplee from the cold vater extraetions wore plased in a round botton Rask and renumed with water for two hour perlod. There was womo afficulty experienoed with those exporiments due to the bunping of the alxture. Extreme axe had to be exeroleod to prevent 20 os of anterials. The reoovered saw dust was tranaforred to an oraporating dish and placed in the oren for drying. After cooling and weighing the seaples wore pleacd in flakk for the other extreotion procese. 
Table IV gives the reaults obtalned in thow extraet1one. The pereontage are based on the orendry weight of the aemple ot the beginning of enoh extrat10n. The table also apporte the theory that the density of the wood is indientive of the emounts of water coluble materials. Flordian and cuban, the two heavient semples used, glve the largest pereentege of extraoted aubutanoes. in exminntion of the colore of the flltrates thow that the Phllipplne wood give amoh 11ghter colored filtrate then do the othor apeales. The flitrates from these experinonts gave realdues ranging from a obocolate color to a light tan. The resldues are very similar in appearance to those obtainod in the cold water extraotion. several attempts wore ande to obtain a epparation of compounds, but nono proved sucoenarul. 
TABLE IV

RESULTS OP HOR WATER BXTRACTIONS

semples oren-dry $\left(108^{\circ} \mathrm{C}.\right)$

\begin{tabular}{|c|c|c|c|c|c|}
\hline spoo108 & $\begin{array}{l}\text { Wolght } \\
\text { of } \\
\text { samplo }\end{array}$ & $\begin{array}{l}\text { Timo } \\
\text { In } \\
\text { noura }\end{array}$ & $\begin{array}{l}\text { Cond1 } \\
\text { tions }\end{array}$ & $\begin{array}{l}\text { color } \\
\text { of } \\
\text { piltrate }\end{array}$ & $\begin{array}{l}\text { Peroent } \\
\text { Extre ot- } \\
\text { od }\end{array}$ \\
\hline $\begin{array}{l}\text { Afrioan } \\
\text { mogany } \\
\text { fl }\end{array}$ & 3.06216 & 8 & rerluxed & 0.1. & 4.04 \\
\hline 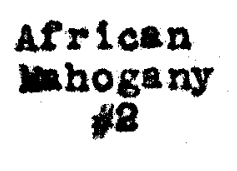 & $5.8865 \mathrm{~g}$ & $\omega$ & " & * & 3.78 \\
\hline $\begin{array}{c}\text { Afrloan } \\
\text { mogany } \\
\text { \#S }\end{array}$ & $3.8488 \mathrm{~g}$ & " & $*$ & $y$ & 3.86 \\
\hline MSAX & $3.0848 \mathrm{~g}$ & " & - & 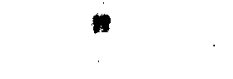 & 3.08 \\
\hline $\begin{array}{c}\text { Mexican } \\
\text { Mahogany } \\
\# 1\end{array}$ & $8.8880 \mathrm{~g}$ & 8 & rerluxed & 0 & 8.08 \\
\hline $\begin{array}{c}\text { Mexican } \\
\text { mohogan } \\
\text { te }\end{array}$ & $3.8689 \mathrm{~g}$ & " & " & $\bullet$ & 3.46 \\
\hline $\begin{array}{l}\text { Mexican } \\
\text { Magogang } \\
\not S\end{array}$ & $3.8470_{\mathrm{B}}$ & - & - & " & 5.36 \\
\hline IEAI & $5.8868 \mathrm{~B}$ & - & $"$ & $\cdot$ & 3.84 \\
\hline $\begin{array}{c}\text { Cuban } \\
\text { Mahogeny } \\
\sharp 1\end{array}$ & 3.73486 & $\mathbf{8}$ & rerluxed & R.o. & 0.16 \\
\hline $\begin{array}{c}\text { Cuban } \\
\text { mogeny } \\
\text { ta }\end{array}$ & $3.7679 \mathrm{~g}$ & $n$ & * & * & 6.89 \\
\hline $\begin{array}{c}\text { Cuban } \\
\text { mahogang } \\
\text { to }\end{array}$ & 3.77238 & $"$ & $*$ & 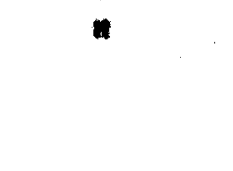 & 5.88 \\
\hline $\mathrm{ren}$ & $3.7760 \mathrm{~s}$ & $"$ & 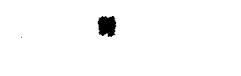 & 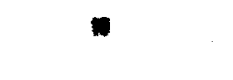 & 6.10 \\
\hline
\end{tabular}


TABIS IV

COMTIMUSD

\begin{tabular}{|c|c|c|c|c|c|}
\hline speotes & $\begin{array}{l}\text { Welght } \\
\text { of } \\
\text { sample }\end{array}$ & $\begin{array}{l}\text { Tiwe } \\
\text { In } \\
\text { Hours }\end{array}$ & $\begin{array}{l}\text { Cond1- } \\
\text { tions }\end{array}$ & $\begin{array}{l}\text { color } \\
\text { of } \\
\text { piltrete }\end{array}$ & $\begin{array}{l}\text { Peroont } \\
\text { Bxtreot- } \\
\text { ad }\end{array}$ \\
\hline $\begin{array}{c}\text { Bonduras } \\
\text { Whogany } \\
\text { I }\end{array}$ & $8.0490 \mathrm{~g}$ & $\mathbf{8}$ & recluxed & H. 0 . & 5.70 \\
\hline $\begin{array}{l}\text { Honduras } \\
\text { Whogens } \\
\text { the }\end{array}$ & $3.9507 \mathrm{~g}$ & 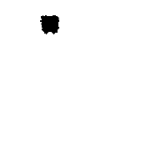 & $n$ & $\bullet$ & 5.88 \\
\hline $\begin{array}{c}\text { Honduraa } \\
\text { mogans } \\
\text { \#s }\end{array}$ & 5.04898 & $n$ & " & * & 5.45 \\
\hline MRAI & $3.0488 \mathrm{~g}$ & $\bullet$ & $\approx$ & • & 5.66 \\
\hline $\begin{array}{c}\text { Romidien } \\
\text { mogogeny } \\
\text { I }\end{array}$ & $3.3847_{\mathrm{g}}$ & $\mathbf{z}$ & rof $l u x e d$ & R. 0. & 10.88 \\
\hline $\begin{array}{c}\text { Poridian } \\
\text { mogony } \\
\text { ps }\end{array}$ & $3.1008 \mathrm{~g}$ & - & $n$ & $\bullet$ & 12.25 \\
\hline $\begin{array}{l}\text { Pox 1alas } \\
\text { vahogn } \\
\text { t3 }\end{array}$ & $3.3080 \mathrm{~B}$ & 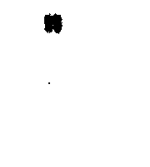 & $\bullet$ & - & 10.02 \\
\hline max & 3.30856 & . & - & " & 10.08 \\
\hline $\begin{array}{c}\operatorname{Bag}= \\
\operatorname{tin} \operatorname{lan} \\
+1\end{array}$ & 3.08808 & 8 & rerluxed & $0 . y .2 .1$ & 2.70 \\
\hline$\frac{\operatorname{Bag}}{\operatorname{tol} \operatorname{lan}^{2}}$ & $3.0880 \mathrm{~g}$ & $n$ & " & $n$ & 2.34 \\
\hline $\begin{array}{c}\text { Bag- } \\
\text { tionan } \\
48\end{array}$ & $3.9408 \mathrm{~g}$ & $n$ & . & n & 8.48 \\
\hline $\operatorname{men} x$ & $3.0580 \mathrm{~g}$ & n & $"$ & $n$ & 2.50 \\
\hline
\end{tabular}


TABLE IV

COMP IMUED

\begin{tabular}{|c|c|c|c|c|c|}
\hline speo1ec & $\begin{array}{c}\text { wejt } \\
\text { of } \\
\text { somplot }\end{array}$ & $\begin{array}{l}\text { Pla } \\
1 x \\
\text { soure }\end{array}$ & $\begin{array}{l}\text { Conds- } \\
\text { tolone }\end{array}$ & $\begin{array}{l}\text { color } \\
\text { of } \\
\text { plitrute }\end{array}$ & $\begin{array}{l}\text { Feraent } \\
\text { axtrant } \\
\text { ad }\end{array}$ \\
\hline $\begin{array}{r}\text { Whes } \\
\text { Inun }\end{array}$ & 8.07158 & 8 & pelured & $0.1 . I . I$ & .39 \\
\hline $\begin{array}{l}\text { Whets } \\
\text { rema }\end{array}$ & 3.96858 & $\omega$ & $\bullet$ & $\bullet$ & .20 \\
\hline $\begin{array}{r}\text { Whete } \\
\text { rana }\end{array}$ & 3.97308 & 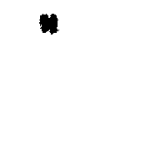 & $n$ & 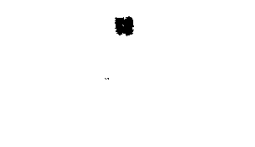 & .32 \\
\hline MRAL & 3.07138 & ! & 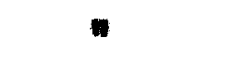 & $\bullet$ & .81 \\
\hline $\begin{array}{l}\text { ned } \\
\text { fest } \\
f_{2}\end{array}$ & $3.9679 \mathrm{~h}$ & 8 & refluxed & $0 . X . T . I$ & 2.47 \\
\hline $\begin{array}{l}\text { Red } \\
\text { Law }\end{array}$ & $\$ .06028$ & $\omega$ & y & a & 8.34 \\
\hline $\begin{array}{l}\text { fro } \\
\text { Inte }\end{array}$ & 3.97808 & m & 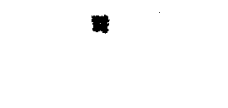 & - & 2.51 \\
\hline ax & 8.06078 & $*$ & $\omega$ & $\bullet$ & 2.44 \\
\hline $\begin{array}{l}2 \operatorname{lng} \\
421 \\
81\end{array}$ & 3.0893 & 8 & seslured & 0.1 .2 .1 & 1.28 \\
\hline$\frac{\operatorname{man}}{\mathrm{n} 1 \mathrm{n}}$ & $3.9600 \mathrm{~B}$ & w & 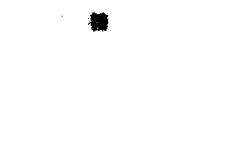 & $*$ & 2.08 \\
\hline$\frac{\operatorname{mag}}{12}$ & 3.06238 & $\bullet$ & $\mathbf{n}$ & 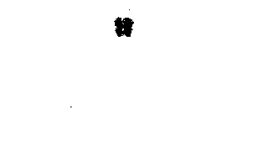 & 1.80 \\
\hline MA & $3.0006 \mathrm{~s}$ & 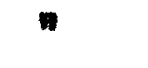 & $\varpi$ & 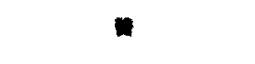 & 1.16 \\
\hline
\end{tabular}




\section{Sther Rxtragtion}

ung regkne and olcorosine aro oxtreated from wod wth other. In 17 oorroepondenoe with the Forest Producte Laboratory it we augested that $I$ remove the realin or memogeny gum by diveosving it in other. but this wethod we uneatiefaotory. Thore remains a great wount of obuay before the wajeot of

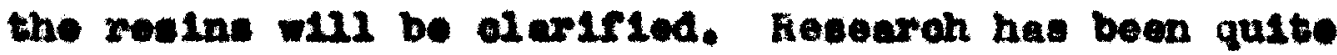
aetive in the atudy of oleoreating from the condrert. It has beon polnted out that there are over ninety oonifere epeoser in the United states. Compuretively rew of the resine and oleorealine hive been oxtracted and exmined (B). In cone Inatances esential olle have been extracted from the waete sev duet or chavinge of varions incuetries. At present. the waste produote from mahogeny axe being used for fuel.

\section{Expoximentax}

The cuples uned in the hot water oxtragtlone were allowat to coek in other for poriod of eixty-eix boure. The onv dunt we cozleoted in an oreporating aidh and Alowed to ary in tho alr for two hours, artor widh they were pleoed in the oven for surther dryins. The emples bolns wolghed vero traneforred to a Mank 
for the sodium hydroxlde extractions.

Table V gives the resulta obtalned in these extractions. The results do not show any great alfroxenoes in the extracted mounts. As alase, the Afrieen and the true wahoganles do wow a elightz larger pereentege of extraoted substences. Forialen mahogany shows the hicheat pereentege of ether soluble materials, and Eondurne showe the Iowent peroentage. Addit Ional Investigation, veing a lurger number of sanples, It necoseary before any conelustons oan be reached as to the other soluble content. The flitrate from these oxtraotion are colorlon with the excoption of those from F2orlalan and Fangulle. The Table does not 21at ans color for rangusle however, there is just the falntest shade of orange present after the ether has boen reduced to anell volune. The residue after evaporation of the ether wae In the form of flobwies of oll of fat of reddieh color. The color of the reasdue veried with the elitrates. Thoee from the PhILLppine woods gave a wah 21ghter colored subetanoe then those of the other apectes. no sttempt was ade to ldentify the cubstanses extreoted. 
TABLS V

RBSULTS OF ETHER EXTKACT IOUS

Samples oren-dry $\left(105^{\circ} \mathrm{C}.\right)$

\begin{tabular}{|c|c|c|c|c|c|}
\hline speoles & $\begin{array}{l}\text { wofght } \\
\text { of } \\
\text { semples }\end{array}$ & $\begin{array}{l}\text { Pine } \\
\text { in } \\
\text { Houre }\end{array}$ & $\begin{array}{l}\text { Cond1- } \\
\text { tions }\end{array}$ & $\begin{array}{l}\text { color } \\
\text { of } \\
\text { piltrate }\end{array}$ & $\begin{array}{l}\text { Percont } \\
\text { Extraot- } \\
\text { od }\end{array}$ \\
\hline $\begin{array}{c}\text { African } \\
\text { wabogany } \\
\# 2\end{array}$ & 3.70808 & 66 & $\begin{array}{l}\text { erequent } \\
\text { ohaking }\end{array}$ & $\begin{array}{l}\text { no } \\
\text { Color }\end{array}$ & 8.68 \\
\hline $\begin{array}{l}\text { Afrioan } \\
\text { inhogany } \\
\text { ge }\end{array}$ & $3.7070 \mathrm{~g}$ & $n$ & - & $n$ & 2.29 \\
\hline $\begin{array}{c}\text { African } \\
\text { magogny } \\
\text { \#5 }\end{array}$ & $3.6971_{\mathrm{g}}$ & " & " & $n$ & 2.50 \\
\hline MBA & 3.70838 & " & $"$ & - & 2.40 \\
\hline $\begin{array}{c}\text { Moxioen } \\
\text { Whogeny } \\
\# 2\end{array}$ & 3.74038 & 66 & $\begin{array}{l}\text { froquent } \\
\text { mking }\end{array}$ & $\begin{array}{c}\text { no } \\
\text { color }\end{array}$ & 3.38 \\
\hline $\begin{array}{l}\text { Maxicin } \\
\text { Mahogamy } \\
\text { t2 }\end{array}$ & $3.7348 \mathrm{~g}$ & $n$ & $*$ & $\bullet$ & 3.44 \\
\hline $\begin{array}{c}\text { Mox loan } \\
\text { whogeny } \\
\text { t3 }\end{array}$ & 3.71898 & $*$ & $n$ & $n$ & 2.87 \\
\hline UEAY & $3.8351 \mathrm{~g}$ & $n$ & $n$ & w & 3.26 \\
\hline $\begin{array}{l}\text { Cuban } \\
\text { magany } \\
\# 1\end{array}$ & $3: 65168$ & 66 & $\begin{array}{l}\text { Irequent } \\
\text { abaking }\end{array}$ & $\begin{array}{l}\text { no } \\
\text { color }\end{array}$ & 2.58 \\
\hline $\begin{array}{c}\text { Cuban } \\
\text { Mhogany } \\
p^{2}\end{array}$ & 3.5525 & $\bullet$ & " & 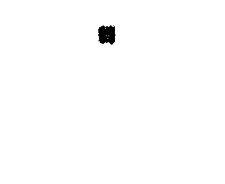 & 2.23 \\
\hline$\underset{f 3}{\text { Cuben }}$ & $3.5507 \mathrm{~g}$ & $n$ & $n$ & $n$ & 2.46 \\
\hline MEAT & $3.5449 \mathrm{~g}$ & 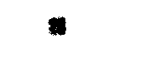 & " & " & 2.36 \\
\hline
\end{tabular}


TABLS $v$

CONTINUED

\begin{tabular}{|c|c|c|c|c|c|}
\hline spoolos & $\begin{array}{l}\text { Wolght } \\
\text { of } \\
\text { semples }\end{array}$ & $\begin{array}{l}\text { Ins } \\
\text { in } \\
\text { Hours }\end{array}$ & $\begin{array}{l}\text { Condi- } \\
\text { tions }\end{array}$ & $\begin{array}{l}\text { color } \\
\text { of } \\
\text { riltrete }\end{array}$ & $\begin{array}{l}\text { poroent } \\
\text { Extract- } \\
\text { ed }\end{array}$ \\
\hline $\begin{array}{c}\text { Honduras } \\
\text { hogeny } \\
\text { II }\end{array}$ & 3.72386 & 66 & $\begin{array}{l}\text { frequent } \\
\text { ohaking }\end{array}$ & $\begin{array}{l}\text { no } \\
\text { color }\end{array}$ & .56 \\
\hline 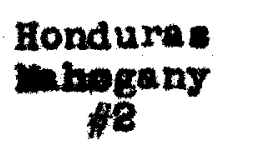 & 3.71968 & * & $"$ & $\bullet$ & .54 \\
\hline $\begin{array}{c}\text { Bonduras } \\
\text { mahoganj } \\
\text { t5 }\end{array}$ & $3.7570 \mathrm{~g}$ & " & • & * & .60 \\
\hline MBAX & $3.7247 \mathrm{~g}$ & " & - & $"$ & .57 \\
\hline $\begin{array}{c}\text { Loridian } \\
\text { mogany } \\
41\end{array}$ & $3.0188 \mathrm{~g}$ & 66 & $\begin{array}{l}\text { Erequent } \\
\text { nhaking }\end{array}$ & $\begin{array}{l}\text { no } \\
\text { color }\end{array}$ & 4.41 \\
\hline $\begin{array}{c}\text { Foridian } \\
\text { mogany } \\
\text { te }\end{array}$ & $3.0218 \mathrm{~g}$ & $*$ & " & $n$ & 4.73 \\
\hline $\begin{array}{l}\text { Roridian } \\
\text { Mhogany } \\
\text { ms }\end{array}$ & $3.0818 \mathrm{~g}$ & n & - & $"$ & 4.31 \\
\hline MEAI & 3.08058 & $n$ & 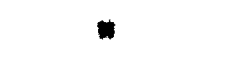 & " & 4.48 \\
\hline $\operatorname{ligh}_{42}$ & $3.0865 \mathrm{~g}$ & 66 & $\begin{array}{l}\text { frequent } \\
\text { ahaking }\end{array}$ & $\begin{array}{l}\text { no } \\
\text { oolor }\end{array}$ & 2.09 \\
\hline $\operatorname{Bag}_{48}$ & $3.8368 \mathrm{~g}$ & $*$ & " & $n$ & 2.06 \\
\hline$\frac{\text { Bas- }}{\text { tiona }}$ & 3.84248 & $n$ & $n$ & 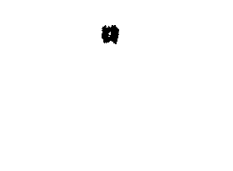 & 2.07 \\
\hline MEAX & 3.88518 & 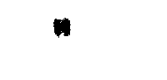 & " & " & 2.04 \\
\hline
\end{tabular}


TABEE $V$

Come InURD

\begin{tabular}{|c|c|c|c|c|c|}
\hline Speotos & $\begin{array}{c}\text { uelght } \\
\text { of } \\
\text { snmplos }\end{array}$ & $\begin{array}{l}\text { Plno } \\
\text { in } \\
\text { roura }\end{array}$ & $\begin{array}{l}\text { Cond1- } \\
\text { ti one }\end{array}$ & $\begin{array}{l}\text { 6olor } \\
\text { of } \\
\text { plerete }\end{array}$ & $\begin{array}{l}\text { Paroent } \\
\text { Fxtrat } \\
\text { ad }\end{array}$ \\
\hline 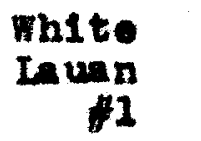 & $3.0898 \mathrm{~g}$ & 66 & $\begin{array}{l}\text { reguent } \\
\text { haking }\end{array}$ & $\begin{array}{c}\text { no } \\
0010 r\end{array}$ & 1.68 \\
\hline $\begin{array}{r}\text { White } \\
\text { reunn }\end{array}$ & $3.0567 \mathrm{~s}$ & $n$ & $n$ & $n$ & 1.61 \\
\hline $\begin{array}{l}\text { white } \\
\text { raman }\end{array}$ & 3.06288 & $\bullet$ & - & e & 1.58 \\
\hline MRAN & $8.0526 \mathrm{~s}$ & ต & $*$ & $\boldsymbol{n}$ & 1.50 \\
\hline $\begin{array}{l}\text { Rod } \\
\operatorname{Lana} \\
\qquad 1\end{array}$ & 3.86968 & 66 & $\begin{array}{l}\text { s requent } \\
\text { thelng }\end{array}$ & $\begin{array}{l}\text { no } \\
0020 x\end{array}$ & 2.86 \\
\hline $\begin{array}{l}\text { Red } \\
\operatorname{Tann} \\
\frac{48}{V^{2}}\end{array}$ & 3.8764 & - & * & $*$ & 8.31 \\
\hline $\begin{array}{l}\text { Red } \\
\text { Inun } \\
\text { tos }\end{array}$ & 3.67898 & $\bullet$ & 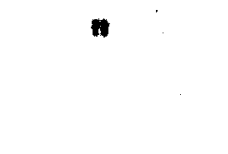 & $\bullet$ & 2.26 \\
\hline Urax & $3.8787 \mathrm{~s}$ & 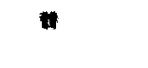 & $\mathbf{n}$ & a & 8.27 \\
\hline $\begin{array}{r}\operatorname{xang} \\
4118 \\
\$ 1\end{array}$ & $3.9118 \mathrm{E}$ & 66 & $\begin{array}{l}\text { Prequent } \\
\text { chlitus }\end{array}$ & $\begin{array}{c}\text { no } \\
\text { colos: }\end{array}$ & 1.52 \\
\hline $\begin{array}{c}\text { mans- } \\
4120 \\
48\end{array}$ & 3.39188 & 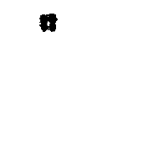 & $n$ & 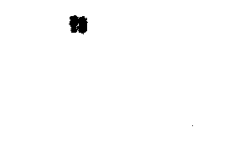 & 1.65 \\
\hline $\begin{array}{l}\min s- \\
\operatorname{412}=\end{array}$ & 3.91868 & 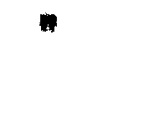 & : & $*$ & 1.40 \\
\hline $\mathrm{mal}$ & $3.9249 g$ & $\omega$ & $*$ & 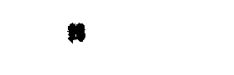 & 1.69 \\
\hline
\end{tabular}




\section{cold sodiun Hydroxide Extraction.}

Alkall has no specific action on wood, however. it attack a number of the alfferent components (8). Aoooralng to knwley and Hie, allute oodium hydroxide solutiona rewove a part of the $11 \mathrm{gnin}$ and part of the hemloelluloses. The herdwoods, which contaln a higher percontage of pentosane, are attacked oy alkuli treatment moxe than re other woods. However. Individual samples of sume a of woods have been found to have a nigher percentage of alkall soluolo subatances than do certain samples of hard wooda (8).

It has been determined that extruction ith alka11 alters the homloelluloses (13). some wood gune, after 1aclation with 4 lka11, becone soluble in weter. Little Xylan, Araban, or vanan oan bo lsoleted Ith bolling water alone; however, onoe removed with alkal1 treatmont thoy do become soluble in water. Experimental

The sumpion from the ether extractione were oxtrasted with 48 sodium hydroxide for period of elghteen houre. After filtering and washing. the adaut was returned to tho oven for dxying. Aftor drylng, it a carefully oxumined through hand lons. From all appearancea, the condition of the material was not altared by this extraotion. 
The doposits of gum in the oamples of Arrionn and Tropleal Awerican makany romained although they did show wight softening. Table VI gives the results of those extractions. It appeare thet these peroontages as celculated for the African and roploal apecles is somew bat blgh; however, there is no way to ohook the reoulta except through oddltional reaearohes. The f11trates from these extreotions presont an interesting point. The color obtained with the Ph111pplne wooda range from orange to tint of orange yellow, whlle the colors of the other epecles are 11 of the orenge red shade. The philipplne

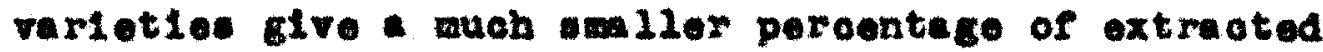
subatance than do the Afrion and Froplcal maboganles. The filtrete wae neutralised with wdrooblorio ac1d and a flocculent proolpltate rormed. The PhIllppine wooda gave amaller and 1lghter colored procipitate. This subatance, aftor arying, was found to be soluble in water. Ho ettempt wae made to separate or purify the ubetance. 


\section{TABLE VI}

RBSULFS OF COLD SODIOX EYDROXIDB EXTKACTIOAS

samples oren-dry $\left(108^{\circ} \mathrm{C.}\right)$

Speoles

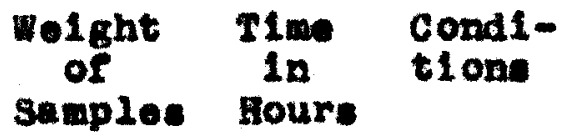

18

African

whogeny

12

Afrionn

Hahogany

is

Afrloan

mhogany

43

man

$\operatorname{Mox} 10 a n$

mogany

1

Mexicen

Mabogany

$\$ 2$

Mexican

hogany

as

$$
3.60888
$$

3.61708

$\mathbf{a}$

bhaking

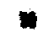

$3.6180 \mathrm{~g}$

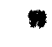
buking

$3.6070_{\mathrm{g}}$

a
Prequent

Color

of

pitrete

$0 . R$.

29.98

27.68

29.66

*.

Percent gxtracted

*

29.21

38.49

0.R.

a

33.19

๓

32.50

uran

$3.6097 \mathrm{~g}$

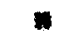

a

เ

32.74

Cuban

wogany

$$
3.4668 \text { g }
$$

18

frequent chaking

O.R.

25.85

|l 1

Cuban

$$
3.46368
$$

*

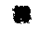

15.84

mhogany

48

Cuban

3.46318

$\omega$

$n$

16.33

riborat

4 
TABIS VI

CONT INUED

\begin{tabular}{|c|c|c|c|c|c|}
\hline spooles & $\begin{array}{l}\text { molght } \\
\text { of } \\
\text { sample }\end{array}$ & $\begin{array}{l}\text { T1mo } \\
\text { In } \\
\text { Houra }\end{array}$ & $\begin{array}{l}\text { Cond1- } \\
\text { tions }\end{array}$ & $\begin{array}{l}\text { Color } \\
\text { of } \\
\text { piltrate }\end{array}$ & $\begin{array}{l}\text { Percont } \\
\text { Bxtraot- } \\
\text { ad }\end{array}$ \\
\hline $\begin{array}{c}\text { Honduras } \\
\text { Mahogany } \\
\text { \#1 }\end{array}$ & $3.7088 \mathrm{~g}$ & 18 & $\begin{array}{l}\text { froquont } \\
\text { oheking }\end{array}$ & $0 . R$. & 17.16 \\
\hline $\begin{array}{c}\text { Eondura } \\
\text { mogheny } \\
\text { fz }\end{array}$ & $3.6006 \mathrm{~g}$ & $n$ & $"$ & $n$ & 18.07 \\
\hline $\begin{array}{c}\text { Bonduras } \\
\text { Lhogeny } \\
\text { t5 }\end{array}$ & $3.7077 \mathrm{~s}$ & $n$ & " & $*$ & 17.65 \\
\hline $\max$ & $3.7033 g$ & " & " & 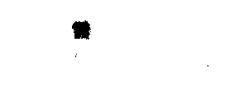 & 17.68 \\
\hline $\begin{array}{c}\text { Fiorialan } \\
\text { whogng } \\
\text { fi }\end{array}$ & $2.8848_{8}$ & 18 & $\begin{array}{l}\text { frequent } \\
\text { shaking }\end{array}$ & $0 . \mathbb{R}$. & 14.50 \\
\hline $\begin{array}{c}\text { Florid Ian } \\
\text { whogany } \\
78\end{array}$ & $8.8783 \mathrm{~g}$ & $n$ & $n$ & $n$ & 24.09 \\
\hline $\begin{array}{l}\text { Foridian } \\
\text { Mhogany } \\
\end{array}$ & 2.80138 & " & $n$ & $"$ & 24.51 \\
\hline $\operatorname{men}$ & $2.8848 \mathrm{~B}$ & " & n & $"$ & 14.36 \\
\hline$\frac{\operatorname{Bag}}{\operatorname{tg} \operatorname{lan}^{-}}$ & $3.7500 \mathrm{~g}$ & 28 & $\begin{array}{l}\text { Erequent } \\
\text { anaklng }\end{array}$ & 0. & 8.41 \\
\hline $\operatorname{tictan}$ & 3.75788 & $"$ & " & $n$ & 9.28 \\
\hline${ }^{\text {Bagian }}$ & $3.7686 \mathrm{~g}$ & 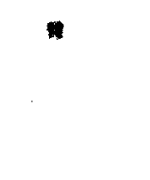 & $n$ & $n$ & 9.60 \\
\hline $\operatorname{sen} x$ & $3.7567_{6}$ & $"$ & 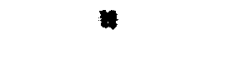 & $n$ & 9.42 \\
\hline
\end{tabular}


TABLE VI

CONT IKUED

\begin{tabular}{|c|c|c|c|c|c|}
\hline speoses & $\begin{array}{c}\text { yelebt } \\
\text { ar } \\
\text { gamplet }\end{array}$ & $\begin{array}{l}\text { the } \\
\ln \\
\text { gonre }\end{array}$ & $\begin{array}{l}\text { cond1 - } \\
\text { tions }\end{array}$ & $\begin{array}{l}\text { color } \\
\text { or } \\
\text { Filtrate }\end{array}$ & $\begin{array}{l}\text { Peroent } \\
\text { Betrot } \\
\text { ed }\end{array}$ \\
\hline $\begin{array}{r}\text { nates } \\
\operatorname{tana}\end{array}$ & 3.00868 & 18 & $\begin{array}{l}\text { Eroquent } \\
\text { bukins }\end{array}$ & 0.1 .2 .1 & 3.63 \\
\hline $\begin{array}{r}\text { White } \\
\text { Leun } \\
48\end{array}$ & 3.80878 & $\mathbf{a}$ & $\mathbf{w}$ & w & 3.66 \\
\hline $\begin{array}{r}\text { mite } \\
\text { Laven }\end{array}$ & $3.8898 \mathrm{~B}$ & $\bullet$ & $n$ & - & 3.56 \\
\hline MRAX & $3.8963 \mathrm{~s}$ & 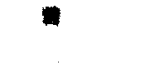 & - & 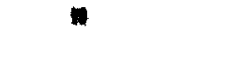 & 5.88 \\
\hline$\frac{\operatorname{Red}}{\operatorname{Lan}}$ & $3.7810 \mathrm{~g}$ & 28 & $\begin{array}{l}\text { erequent } \\
\text { enakins }\end{array}$ & $\mathbf{x} .0$ & 5.00 \\
\hline $\begin{array}{l}\text { Rea } \\
\operatorname{Lann}\end{array}$ & $3.7867 \mathrm{~s}$ & 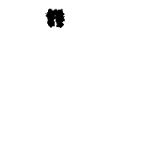 & $n$ & 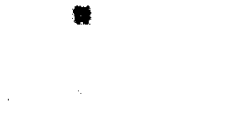 & 5.94 \\
\hline $\begin{array}{l}\text { Red } \\
\text { Iav }\end{array}$ & 3.7988 & 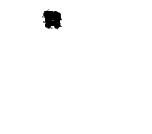 & $n$ & 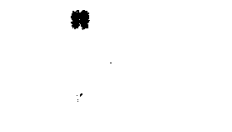 & 5.88 \\
\hline $\max$ & $3.7839 \mathrm{~s}$ & $n$ & 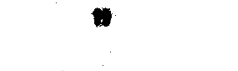 & $n$ & 5.83 \\
\hline & 3.85168 & 18 & $\begin{array}{l}\text { Iroquent } \\
\text { unaking }\end{array}$ & $\Psi .0$. & 4.88 \\
\hline & $3.8640 \mathrm{c}$ & $n$ & $n$ & 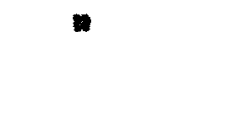 & 4.08 \\
\hline $\begin{array}{l}\text { xar } \\
\text { vit }\end{array}$ & $5.8598 \mathrm{~B}$ & + & $"$ & $n$ & 4.67 \\
\hline $\operatorname{MBA}$ & 3.85628 & $n$ & $\omega$ & $\bullet$ & 4.88 \\
\hline
\end{tabular}


Hot sodium Hydroxide Extractions

Extracting sawdust wh bolling rive percent codium hydroxide for a period of fourtion hours was a pretty harah extraetion process. In thil extrection preotically all the remining extranoous componente of the wood were removed along w1th other substances. Tal. particular extraction wa carriod out solely for the purpose of showing that it does rewore the gum aubstance of magogany. The other extraotione proved that this abetance does resist the cotion of cold water, hot water, ether and cold sodium hydroxide. No, doubt a quantity of the lignin contont of the samplos wero remored in theos extraction. Schorger (13) states that ome of the $11 \mathrm{gn} I n$ content 10 romored oven through extraction with cold sodium bydroxide solutions.

\section{Experimontal}

The samples uned in the oold sodiun hydroxide extraotione were tranaforred to liter flacke conneoted wth reflux condenore. The amples were allowed to digest in vigorously bolilng five peroent odium hydroxide for fourteon oontinuow hours. Table vII ohowe the poroentage of extraoted teriale for these extraotions. The algnifieance of these extraotions was not vory olear. 
The Pilippino woods, although totally laoking in the gum content that is typlcal of tia other mahoganies, showed in scme cases larger percantages than any of the other spocies. For Instanoe Bagtiolan Ea vo results as high forty poroont, while African ahogeny, contalning lareor quantity of the gum gave only twenty-one porcent of extraoted abstanoe. the flitrates of the two eroup showed oolor distinctions ofmlar to those of the cold odium hydroxide extrations. The filtratos fulled to givo - precipitate when noutrallzed w1th aold; however, It was found that procipitate formed when an oqual volume of alconol or eoetone wa added. This preclpitate wa recovered on pilter peper and dried The terlals were soluble in water, but insoluble in many of the organie solvente such as aloobol, other, ohlorform, and acetone. However, there was a silght softening in bencene, gasollne and kerosene. Varlous methods of reducing the substance to separute colapounds were unaucoessful. 


\section{TABLB VII}

FESULFS OF HOT SOD TUM FYDHOXIDB EXTHACTIONS

$$
\text { sauplos ovon-dry }\left(105^{\circ} \mathrm{C}_{.}\right)
$$

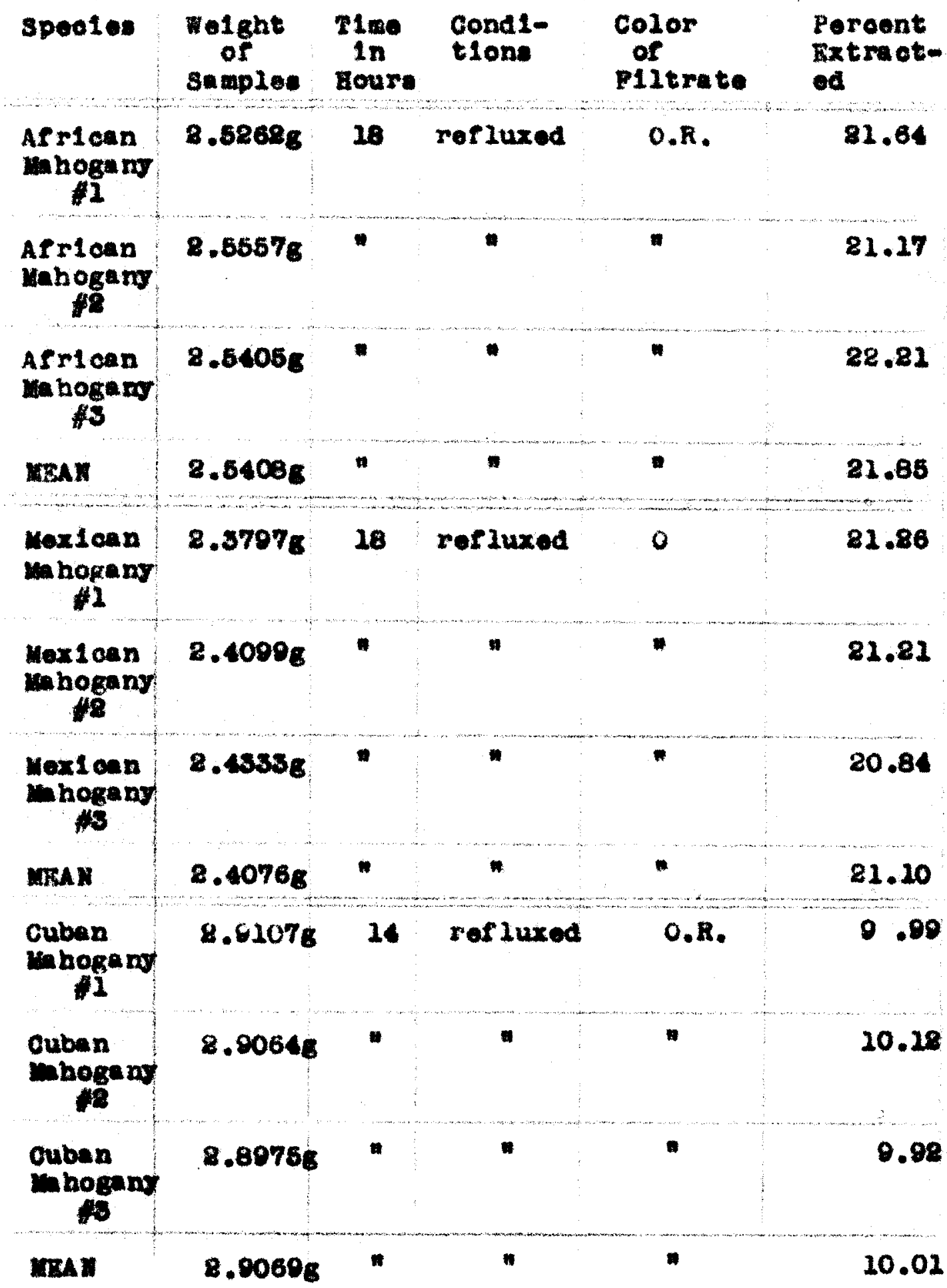


2ABLF VII

CONP INUSD

\begin{tabular}{|c|c|c|c|c|c|}
\hline species & $\begin{array}{c}\text { Gelght } \\
\text { of } \\
\text { semplos }\end{array}$ & $\begin{array}{l}\operatorname{Lan} \\
\ln \\
\text { Roure }\end{array}$ & $\begin{array}{l}\text { cond1- } \\
\text { tione }\end{array}$ & $\begin{array}{l}\text { color } \\
\text { or } \\
\text { plitrete }\end{array}$ & $\begin{array}{l}\text { Percent } \\
\text { Extrat- } \\
\text { ed }\end{array}$ \\
\hline $\begin{array}{c}\text { Eondura } \\
\text { Mhogan } \\
\qquad 1\end{array}$ & $3.06 \% 28$ & 14 & refiured & $0 . \pi$ & 38.00 \\
\hline $\begin{array}{c}\text { Horduras } \\
\text { Hahogeta } \\
\text { fs }\end{array}$ & 3.08968 & $\bullet$ & 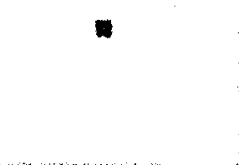 & $\bullet$ & 41.00 \\
\hline $\begin{array}{l}\text { Eondures } \\
\text { Ua hogany }\end{array}$ & 8.0538 & 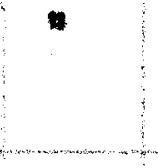 & 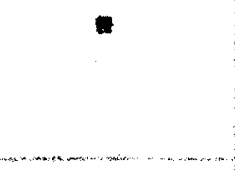 & $\bullet$ & 38.82 \\
\hline $\operatorname{MrA}$ & 3.04998 & $\mathbf{n}$ & 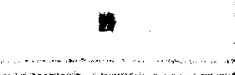 & 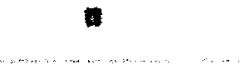 & 39.36 \\
\hline $\begin{array}{c}\text { Poridien } \\
\text { mogeny }\end{array}$ & 0.46688 & 24 & notluxed & 1.8 .1 & 80.4 \\
\hline $\begin{array}{c}\text { Forialan } \\
\text { vobogany } \\
h^{n}\end{array}$ & 8.4758 & $n$ & $\bullet$ & 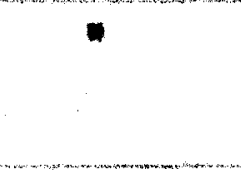 & 86.86 \\
\hline $\begin{array}{c}\text { Lortalan } \\
\text { labogany } \\
58\end{array}$ & $0.4703 \mathrm{~s}$ & 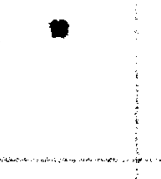 & $*$ & $\mathbf{n}$ & 27.10 \\
\hline MEA & $2.4708 \mathrm{~s}$ & 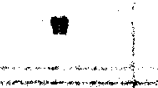 & 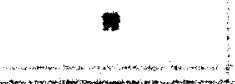 & 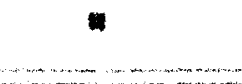 & 39.40 \\
\hline 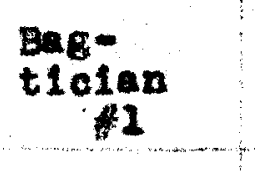 & 3.30718 & 18 & retiuxed & $\mathbf{Y} .0$ & 40.85 \\
\hline $\begin{array}{c}\text { Beg- } \\
\operatorname{tic} \ln n \\
48\end{array}$ & $3.4103 s$ & $\boldsymbol{w}$ & $n$ & n & 40.31 \\
\hline$\frac{\operatorname{Esc}}{\operatorname{tion}}$ & 3.50118 & $\mathbf{n}$ & $n$ & a & 38.01 \\
\hline$A$ & 3.10808 & $n$ & * & 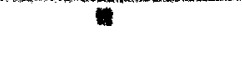 & 39.68 \\
\hline
\end{tabular}


TABEF VII

CONT INUTD

\begin{tabular}{|c|c|c|c|c|c|}
\hline speoles & $\begin{array}{c}\text { welght } \\
\text { of } \\
\text { Sempleo }\end{array}$ & $\begin{array}{l}\operatorname{xin} \theta \\
\ln \\
\operatorname{noux}\end{array}$ & $\begin{array}{l}\text { Cond1- } \\
\text { tone }\end{array}$ & $\begin{array}{l}\text { color } \\
\text { of } \\
\text { 12trato }\end{array}$ & $\begin{array}{l}\text { Percent } \\
\text { Extrast } \\
\text { ad }\end{array}$ \\
\hline $\begin{array}{r}\text { Whtte } \\
\tan \\
\$ 2\end{array}$ & $3.7569 \mathrm{E}$ & 24 & refluxed & 0.2 & 26.16 \\
\hline $\begin{array}{l}\text { White } \\
\text { raman }\end{array}$ & $3.7508 \mathrm{~s}$ & - & $\mathbf{n}$ & 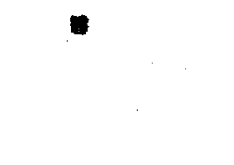 & 17.40 \\
\hline $\begin{array}{r}\text { Whito } \\
\text { tama }\end{array}$ & 3.79088 & 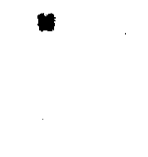 & - & $*$ & 16.50 \\
\hline IEA A & 5.75568 & : & $\mathbf{w}$ & 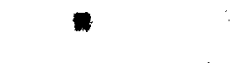 & 16.68 \\
\hline $\begin{array}{l}\text { Rea } \\
\text { Lavan }\end{array}$ & $3.5588 \mathrm{~s}$ & 24 & rerluxed & 0. & 87.82 \\
\hline $\begin{array}{l}\text { Rod } \\
\text { Laman }\end{array}$ & $\$ .5617 \mathrm{~s}$ & 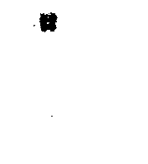 & * & $\mathbf{a}$ & 87.09 \\
\hline$\frac{\text { Red }}{\operatorname{lan} x}$ & $3.6607 \mathrm{~g}$ & * & * & $\mathbf{v}$ & 26.81 \\
\hline MEAK & 3.55928 & - & n & 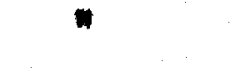 & 27.23 \\
\hline $\begin{array}{c}\operatorname{Tans}- \\
4128 \\
\frac{1}{4}\end{array}$ & 3.66898 & 14 & refluxed & $0 . X$ & 27.36 \\
\hline $\begin{array}{c}\text { Tans- } \\
\text { u11e } \\
\text { he }\end{array}$ & $3.6629 \mathrm{a}$ & $n$ & $n$ & $n$ & 27.27 \\
\hline 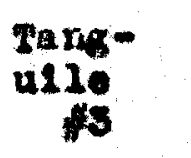 & 8.67638 & $n$ & - & $n$ & 27.88 \\
\hline IEA & $\$ .6683 \mathrm{c}$ & - & $n$ & * & 87.50 \\
\hline
\end{tabular}


PATT IV

Asn colntarn 


\section{Deteruintion of Ash}

The quantitative determinations of the ach oontent of the samplon used in this study are found in reble VIII. There 1s no relation botween the ash content and the speolflo gravity of wood. The table shows that Bagtiolen, having a soolfio. grevity of . 64 mas an ash content of 1.63 paroent wh1le plorlalen mhogany wth opociflo gravity of .98 has only .88 pereent of ash. Sohorger (23) roports that Balsa, one of the 11ghteet of roods, contains 8.0 percent of an.

In gonore 1, the sap wood oontalns a greater poroentege of ash than the heart wood (8). Prequently the anh content is greater in the orown and in the brenohes than in the trunk. The oontent of ash waterlale varles with the age of the tree, usully it 16 found that the older trees show decrease in ash oontent.

Tho prinolpal wetal210 compononte in wood ashes aro culolum, potassium, and manestum. Besldes these, amil amounts of codium, manes, luminum, Iron, sulfates and ohlorides are almost invariably prosont In wood ahes (B). Porhaps the most characterist10, a Ithough seldon the moat abundant component of wood achos 1s potaselum carbonate. The presenoe of this compound expleins the value of wood asbos as a fort1liser and as raw material in the making of 
soft soap. In general, the win oomponent of wood ashes 1. 11we. The aub of sowe of the bard woods bas beon found to run as high as 70 peroont in 11 me (8).

\section{Exporimental}

Three samples of each of the nine speoles were carofully wolghed in tared poroelain oruelbles. The eruelbles with 11da were placed in the muefle furnaco and allowed to remain at a dull red heat for one hour. The 11ds wore romored and the oruolbles wore lort in the oven unt1l oomplote oorbustion had teken plece. oocaselomel stirring inoured a more complote oombustion. The oruolbles were then pleced in the deslocator until 0001 and then wa1Fiod. The determinatione are based on the oren-dry welghts of the samples. Ho attompt was made to andyse the ach further for 1 te varlow elneral componente. 
TABLS VIII

RBSULTS OF ASA DET BHATMY IOWS , samples oven-ary $\left(206^{\circ} 0.\right)$

\begin{tabular}{|c|c|c|c|}
\hline speot os & $\begin{array}{l}\text { Woight of } \\
\text { semple }\end{array}$ & $\begin{array}{l}\text { Wolght of } \\
\text { Aeh }\end{array}$ & $\begin{array}{l}\text { Peroont of } \\
\text { Aab Content }\end{array}$ \\
\hline $\begin{array}{c}\text { Afrioan } \\
\text { mahogeny } \\
\forall 1\end{array}$ & $2.2546 \mathrm{c}$ & $.0456 \mathrm{~g}$ & 3.85 \\
\hline $\begin{array}{l}\text { African } \\
\text { mahoga m } \\
\text { th }\end{array}$ & $1.0800 \mathrm{E}$ & $.0408 \mathrm{~g}$ & 3.83 \\
\hline$\underset{\substack{\text { Afriogn } \\
\text { mogany }}}{\cos }$ & $\mathbf{R} .5950_{\mathrm{g}}$ & $.0089 \mathrm{~g}$ & 3.80 \\
\hline max & $1.5871 \mathrm{~g}$ & $.0609 \mathrm{~g}$ & 3.82 \\
\hline $\begin{array}{c}\text { Moxican } \\
\text { mhogeny } \\
\not 2\end{array}$ & $1.2268 \mathrm{~B}$ & $.0081_{8}$ & .66 \\
\hline $\begin{array}{l}\text { Maxioan } \\
\text { rabogany } \\
\text { the }\end{array}$ & 3.38608 & $.0210 \mathrm{~g}$ & .63 \\
\hline $\begin{array}{l}\text { Moxloan } \\
\text { wahogany } \\
\qquad 5\end{array}$ & $1.3676 \mathrm{~B}$ & .onaras & .60 \\
\hline man & $2.0696 \mathrm{~g}$ & .02138 & .68 \\
\hline $\begin{array}{c}\text { Cuban } \\
\text { Whogang } \\
\qquad 1\end{array}$ & $8.4173_{8}$ & .01868 & .88 \\
\hline $\begin{array}{l}\text { Guben } \\
\text { mogeny } \\
n e\end{array}$ & 2.98048 & $.0280_{8}$ & .80 \\
\hline$\underset{10}{\substack{\text { Guban } \\
\text { Ehogany }}}$ & $1.7070 \mathrm{~g}$ & $.0087 \mathrm{~g}$ & .50 \\
\hline IBAA & $8.3718 \mathrm{~B}$ & .01818 & .61 \\
\hline
\end{tabular}


TABLE VIII

CONIIYUED

\begin{tabular}{|c|c|c|c|}
\hline spoo10a & $\begin{array}{l}\text { Wolght of } \\
\text { sample }\end{array}$ & $\begin{array}{l}\text { Wolght of } \\
\text { anh }\end{array}$ & $\begin{array}{l}\text { Peroont of } \\
\text { Aab content }\end{array}$ \\
\hline $\begin{array}{l}\text { Hond uras } \\
\text { Whogany } \\
\text { TI }\end{array}$ & $2.0478 \mathrm{~g}$ & $.0088_{8}$ & .41 \\
\hline $\begin{array}{l}\text { Hondure: } \\
\text { mogeng } \\
\text { ta }\end{array}$ & $8.1809 \mathrm{~g}$ & $.0088 \mathrm{~B}$ & .40 \\
\hline $\begin{array}{c}\text { Hondura: } \\
\text { Whogens } \\
\text { t5 }\end{array}$ & 2.10716 & .00638 & .48 \\
\hline MEAX & $1.7816 \mathrm{~g}$ & .00718 & .48 \\
\hline $\begin{array}{l}\text { Ploridian } \\
\text { thohogang } \\
\text { I1 }\end{array}$ & 3.28088 & .08068 & .88 \\
\hline $\begin{array}{l}\text { Ploridian } \\
\text { mogany } \\
\text { fe }\end{array}$ & 8.28058 & .01718 & .80 \\
\hline $\begin{array}{l}\text { Ploridian } \\
\text { wahogany } \\
\text { t5 }\end{array}$ & 1.65348 & $.0136 \mathrm{~g}$ & .88 \\
\hline MEAB & 2.30418 & .02048 & .81 \\
\hline $\begin{array}{c}\text { Bagtiolan } \\
\end{array}$ & $1.4510 \mathrm{~g}$ & $.0220 \mathrm{~g}$ & 1.51 \\
\hline $\begin{array}{c}\text { Bagtiolan } \\
n\end{array}$ & 1.60448 & $.0235 \mathrm{~g}$ & 1.56 \\
\hline $\begin{array}{c}\text { Buctiolen } \\
88\end{array}$ & $2.5681_{8}$ & $.0240_{B}$ & 2.64 \\
\hline max & 2.60258 & $.0851_{8}$ & 2.63 \\
\hline
\end{tabular}


RABLS VIII

COHT InUED

\begin{tabular}{|c|c|c|c|}
\hline spectes & $\begin{array}{l}\text { Welght or } \\
\text { semple }\end{array}$ & $\begin{array}{l}\text { Welght of } \\
\text { Leb }\end{array}$ & $\begin{array}{l}\text { Peroent of } \\
\text { Aah content }\end{array}$ \\
\hline 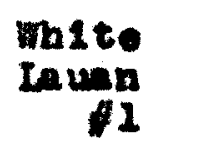 & 8.18308 & $.0000 \mathrm{~s}$ & .48 \\
\hline $\begin{array}{r}\text { White } \\
\text { Tunn } \\
\text { \%8 }\end{array}$ & $1.4008 \mathrm{~g}$ & $.0088 \mathrm{~B}$ & .41 \\
\hline 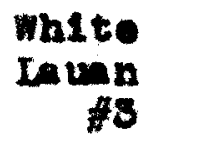 & $2.3400 \mathrm{~s}$ & .00036 & .10 \\
\hline MEAE & $1.0588 \mathrm{~B}$ & $.0090_{8}$ & .42 \\
\hline $\begin{array}{l}\text { Rea } \\
\text { Teman } \\
\frac{4}{2}\end{array}$ & $1.8978 \mathrm{~B}$ & .00038 & .64 \\
\hline$\frac{\text { Rod }}{\operatorname{Lam}}$ & $1.7310 \mathrm{~s}$ & .01098 & .68 \\
\hline $\begin{array}{l}\text { Red } \\
\text { Lavn } \\
48\end{array}$ & 1.2689 & $: 0078 \mathrm{~g}$ & .68 \\
\hline MEAX & $1.4308 \mathrm{E}$ & $.0000 \mathrm{~s}$ & .08 \\
\hline 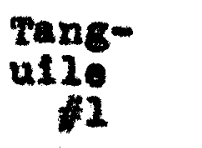 & $1.5668 \mathrm{~s}$ & $.0080 \mathrm{~B}$ & .88 \\
\hline 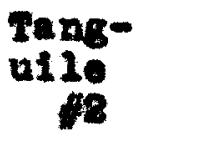 & 2.96568 & $.0058 \mathrm{~s}$ & .30 \\
\hline $\begin{array}{c}\operatorname{mag} \\
\mathrm{n} 1 \mathrm{~S}\end{array}$ & $8.2370 \mathrm{~s}$ & $.0088 \mathrm{~g}$ & .89 \\
\hline UEA & 1.08698 & $.0058_{8}$ & .80 \\
\hline
\end{tabular}


PARY

SPEOIDIO ORAVIMI 
Dotermination of speolfio oratity

The wothod parened for the deterningtion of the speedrio gravities of the smples used in this etudy we concuoted as direoted by the Poreet produote Laboratory (24). The spoctelo exavity of a nood is a good indiontion of the streagth proporties of the wod. But agkin I alght add that to got a true p10ture of the epeoles a larger muber of exuples showle be uoed in all detereshatione. The opeosfio grevity of a oubatenoe is 1te vight alvided by the wolght of an equal volune of vator. The epooiflo gravity doterminations in this study are based on the ovenary semples of k11n Aried woode.

\section{Exporinontial}

Table VIII gives the remulte for these doterminut Lone. Two mothod for oompating the volves of the ongles wore usad however, the table 1s based on the volum as found by noasuremonte. The scuples were cat to exbes, three fourthe of an Inoh in each dinonsion and thesr volumes onloulated in terme of cuble contiesters. The canples were allowed to remain in the oven for elx hours, after which they wore cooled and wolghed. Three eanplos of each opooles wore used. The welehts of the sauplos, as shown in 
the toble, are indicative of the accuracy used in the outting of the sauplos.

A cheok on the volume caloulations was run by determining the emount of mater the wood displeoed when Imwersed. This wa cocomplishod by pleolng beaker of water on the laboratory balanoe and taklng the weight of the container. A glass rod raetened to a stand was used to push the plece of wood under the surface of the water. The samples were dippod In hot paraffin, and any excess was rowoved through sorapling. A am 11 hole was punched in each samplo to ald in keeping it under the water while reading or the weight wa bolng taken. It was found that the determinations, as computed by measurements varied but .02 w 1th those as calculated by diaplecement. The following formula for the determination of the speciflo gravity was used:

$$
\begin{aligned}
& \text { specir1e aravity }=\frac{D}{V} \\
& D=\text { Velght in pram } \\
& v=\text { Volume in } 0.0 \text {. }
\end{aligned}
$$


TABLP

HESOLFS OP SPECIFIC OHAVITY DETSRUTMATIOHS samples orenary $\left(106^{\circ} \mathrm{C}.\right)$

\begin{tabular}{|c|c|c|c|}
\hline speotes & $\begin{array}{l}\text { Weight or } \\
\text { sample }\end{array}$ & $\begin{array}{l}\text { Yolume by } \\
\text { yeacuremont }\end{array}$ & $\begin{array}{l}\text { spoeirio } \\
\text { oruvity }\end{array}$ \\
\hline $\begin{array}{c}\text { Afrioan } \\
\text { mhogany } \\
\# 1\end{array}$ & $8.3484 x$ & 6.91380 .0$. & .48 \\
\hline $\begin{array}{c}\text { Arrican } \\
\text { whogany } \\
\text { hen }\end{array}$ & $3.3050 \mathrm{~s}$ & " & .40 \\
\hline $\begin{array}{c}\text { African } \\
\text { mogany } \\
\text { ts }\end{array}$ & $3.2870_{6}$ & $"$ & .47 \\
\hline MBAI & 3.32548 & * & .48 \\
\hline $\begin{array}{c}\text { Maxican } \\
\text { Mahogany } \\
\qquad 1\end{array}$ & 3.14058 & 6.22380 .0 & .46 \\
\hline $\begin{array}{l}\text { Koxioan } \\
\text { wahogany } \\
\ldots 8\end{array}$ & 8.00796 & $"$ & .46 \\
\hline $\begin{array}{c}\text { Yexloan } \\
\text { hogeny } \\
\# 5\end{array}$ & 3.16808 & w. & .46 \\
\hline $\operatorname{men}$ & $3.1381 \mathrm{~g}$ & * & .48 \\
\hline $\begin{array}{c}\text { Cuben } \\
\text { mbogany } \\
\text { II }\end{array}$ & 3.00808 & 6.01380 .0 & .56 \\
\hline $\begin{array}{l}\text { cuban } \\
\text { mogeny } \\
\text { to }\end{array}$ & $3.0850 \mathrm{~s}$ & - & .68 \\
\hline $\begin{array}{l}\text { Cuban } \\
\text { mogen } \\
\text { gs }\end{array}$ & $4.0400 \mathrm{~g}$ & $n$ & .57 \\
\hline $\operatorname{men}$ & $3.0010 \mathrm{~g}$ & " & .68 \\
\hline
\end{tabular}




\section{TAELS IX}

comr IUUED

\begin{tabular}{|c|c|c|c|}
\hline spooseo & $\begin{array}{l}\text { relght or } \\
\text { semple }\end{array}$ & $\begin{array}{l}\text { Voluma by } \\
\text { Woeverentant }\end{array}$ & $\begin{array}{l}\text { 8peost10 } \\
\text { Oravity }\end{array}$ \\
\hline 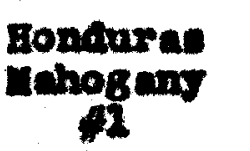 & 3.47608 & 6.02880 .0$. & .60 \\
\hline $\begin{array}{c}\text { Honduras } \\
\text { nehogans } \\
\text { te }\end{array}$ & $3.8600 \mathrm{~s}$ & $\bullet$ & .62 \\
\hline $\begin{array}{l}\text { Eonduras } \\
\text { Dhogany } \\
\text { fo }\end{array}$ & 3.38008 & $*$ & .49 \\
\hline $\operatorname{MBA}$ & $3.4000 \mathrm{~s}$ & $\bullet$ & .60 \\
\hline $\begin{array}{c}\text { Plorialan } \\
\text { uebogeny } \\
y\end{array}$ & 6.29503 & 6.92380. & .91 \\
\hline $\begin{array}{c}\text { Doridan } \\
\text { mahogany } \\
\text { t8 }\end{array}$ & 0.48508 & $\bullet$ & .83 \\
\hline $\begin{array}{l}\text { Ploxidan } \\
\text { Wahogany } \\
\text { fo }\end{array}$ & 6.48808 & * & .98 \\
\hline waris & 6.48408 & 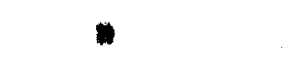 & .08 \\
\hline Begtiotan & 4.40803 & 6.02380 .0 & .68 \\
\hline${ }_{\text {Bagtialan }}$ & 4.46003 & $\bullet$ & .64 \\
\hline Besteleten & 4.48403 & $\bullet$ & .64 \\
\hline mear & 4.48808 & ? & .64 \\
\hline
\end{tabular}


2A ATE IX

COWNINUED

\begin{tabular}{|c|c|c|c|c|}
\hline Speoles & $\begin{array}{l}\text { we1ent of } \\
\text { semplo }\end{array}$ & $\begin{array}{l}\text { Volume } \\
\text { Beabure }\end{array}$ & by & $\begin{array}{l}\text { spoeif10 } \\
\text { oratity }\end{array}$ \\
\hline$\underset{\text { Lmite }}{\operatorname{mana}}$ & 3.16108 & 0.0238 & 0.0 & .46 \\
\hline$\underset{22}{\operatorname{mins}}$ & 3.08003 & $"$ & & $\cdot 44$ \\
\hline 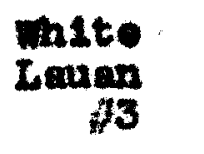 & 5.16808 & $*$ & & .46 \\
\hline$M A$ & 3.22003 & $\bullet$ & & .45 \\
\hline$\underset{\not 1}{\operatorname{Red}}$ & 5.34405 & 0.0238 & 0.0. & .48 \\
\hline $\begin{array}{l}\text { Red } \\
\text { Launen } \\
\qquad 8\end{array}$ & 8.32408 & $*$ & & .47 \\
\hline 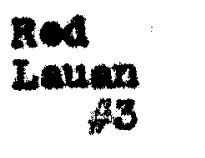 & 3.28708 & 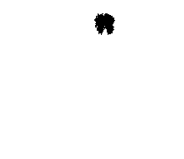 & & .46 \\
\hline man & 3.20203 & $\bullet$ & & .47 \\
\hline $\operatorname{Tang}^{\text {Tans }}$ & .45408 & .8307 & 0.0 & .54 \\
\hline $\begin{array}{l}\text { Tane- } \\
\text { usfe } \\
\frac{4}{18}\end{array}$ & $.4460 \mathrm{~B}$ & $n$ & & .58 \\
\hline 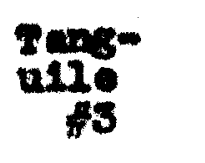 & .43808 & $*$ & & .62 \\
\hline UEAR & .4408 & $\bullet$ & & .68 \\
\hline
\end{tabular}


PATE VI

concrustons 
Conelus lone

The gum that is found in the speoles of Afriton and Troplend amertoen mahogantes is insolublo in wost of the organio olvonts. It 10 bolleved by the writer that there is a posability of finding a volvont for th1s eubstance. Perhape a mixture of several organlo colvente vould bo the anawer to the problem, howerer, such a procedure would requlre an inderinite anount of researoh. The refluxing of the sewdust with five percent sodiun mydroxlde for a perlod of fourteen houre 1. a mothod for the rewovil of the gumes enbstance. Th1e prooese altere the product and is not coneldered entlefactory. The objoot is to extract the metorial and to recover it unohenged and not juet to offoot its removel from the wood.

The reeulte of the various extreotions are indiotive of the faot that there are posalbilitios of obtaining data that way be used in diatingulening the varlous opeoles of mogogany. Indentirioation or mahogany by the oharacter of tas varlere extraot p1Itrates obtalnablo erom thom to an exoellent problem for further rescaroh. An examination of the tables giving the results of the rarlous extractions, suggents that there alght be some rejation between the solublilts of - wood in cortain solvents and tholr speoirlo gravitiea. 
Table $x$ is a aumiry of the enalytion deta obteined in this otudy. This table alffere from the other tables in that the peroentages are baed on the ortginal 4.000 gram weight of the angle. For Inotenoe. the aaple of African moghany wa extruoted " wth cold water and 3.63 pereent of ite weight was diesolved. The romining 3.8681 grame were extraoted wth hot weter and 3.78 peroent of the origina 1.000 grame were removed. This method of caloulation was ueed in all the determintions a shown in Table $x$. The ooope of this partioular problem is vast, and to the best of un knowledge no serlous attempt has over beon wae to bring togethor an analytioal data. perteining colely to the ohemiotiry of manogany. It 1. hoped that this experimentel inveatigation 111 result in a wore thorough and oomprehensive study or the chenteal poesiblittien of the mahoganies. 
TABLE $X$

EXPGRIMENTAL DATA FOUND IN THIS STUDY 
TArax $x$

BXPERTETAT DATA FOUID II TAIS STUDY Revalte in percontage of oren-dry $\left(105^{\circ} \mathrm{C}\right.$ ) vanples

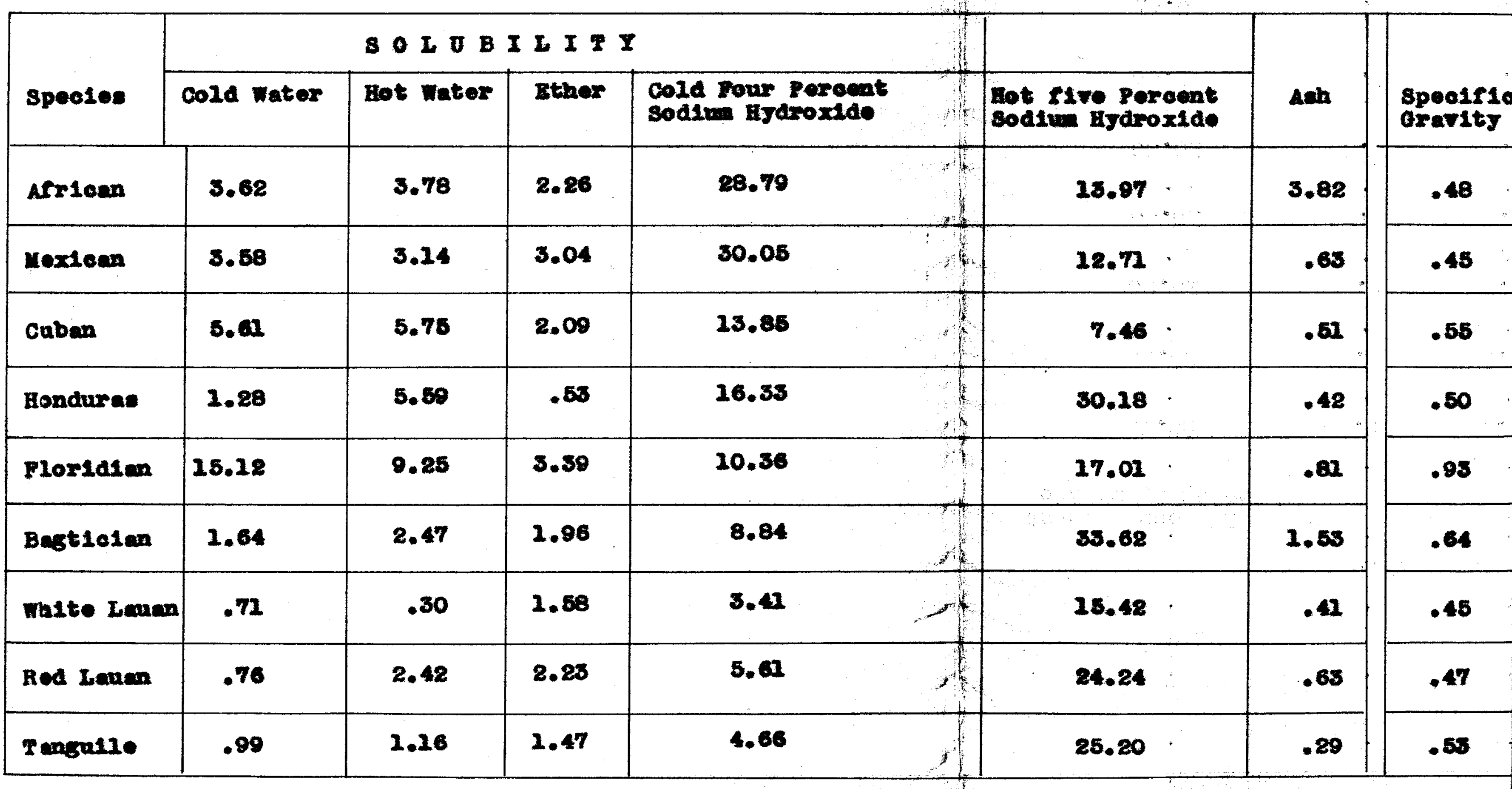




\section{B1bl Lography}

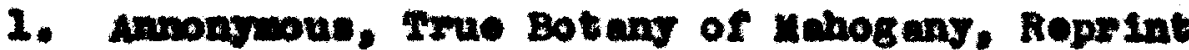

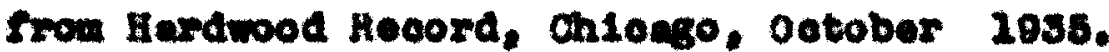

R. Arattrons, Prenidand, The Cerbohydrateo end

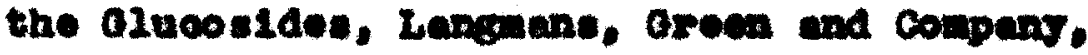
wow Iork, 2984, 107, 196.

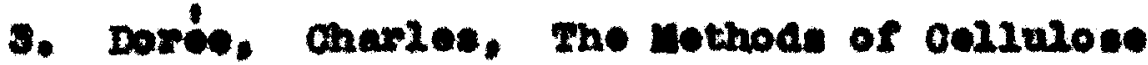
Gantotry D. Von Hootrand Compans. How Yox. 2033. 200 .

4. Fiteche, Fordinna, Prooper fow the Producteon of a subie cum, United state Patent ofriee. Patent 10. 900,874, 1008.

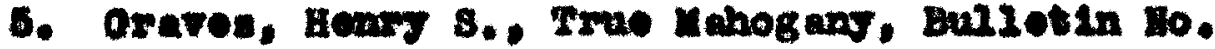
474. Undted states Depertinent of Agriculture. 1907.

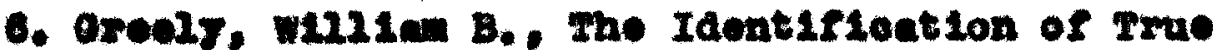
uebogry. Bulietin Do. 2080. Juted staten popartunge of Asrleut ture. 1089.

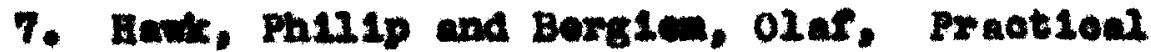

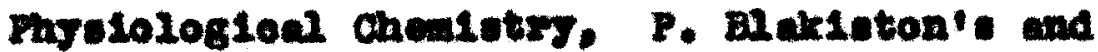
compur. PhIIndel pula, 1027, 891. 
8. Hawley, L.F., and M1*e, L.E., The Chemistry of wood, Gatelog Company, Mow York, 1926, 97-128, 134, 119, 120.

9. Heaten, Hoel, Vozat12 Solvente and Thlnners, D. Van Nostrand Company, New York, 1926.

10. Lamb, George, The Mahogany Book, Mahogany Aasoolation Ino., Chlongo, 1936.

12. mulliken, A Method for the Identifioation of Pure Orgando Compounds, Color Charte, John w11er and Sons, New York, 1904.

12. R1tter, George J., Reoent Correspondence, United statea porest Products Laboratory, JulJ, 1937.

13. Bohorgex, A.W., Chemlatry of Cellulose and wood, MoGraw-B111 Book Company, Hew York, 1926, $241-242,247,86,80$

24. Teohnioal Note, uothod for the Determination of Speo1f10 Grav1ty of Wood, Foreat Producta Laboratory.

16. Thatoher, R.W., The Chonistry of Plant Life, Mocraw-H111 Book Company, Hew York, 2921, 67-75. 